\title{
Impact of Climate Change on Rice and Wheat Yield in Punjab State of India: A District-Level Analysis
}

\author{
Mandeep Bhardwaj \\ Lovely Professional University \\ Pushp Kumar ( $\nabla$ pk27@iitbbs.ac.in ) \\ Indian Institute of Technology Bhubaneswar https://orcid.org/0000-0002-2355-1871 \\ Siddharth Kumar \\ Indian Institute of Technology Bhubaneswar \\ Ashish Kumar \\ Lovely Professional University
}

\section{Research Article}

Keywords: Punjab, Rice, Wheat, FMOLS, DOLS

Posted Date: June 11th, 2021

DOI: https://doi.org/10.21203/rs.3.rs-612890/v1

License: (9) This work is licensed under a Creative Commons Attribution 4.0 International License.

Read Full License 


\title{
Impact of Climate Change on Rice and Wheat Yield in Punjab State of India: A District-Level Analysis
}

\author{
Mandeep Bhardwaj \\ Department of Economics, School of Business \\ Lovely Professional University, Jalandhar, Punjab 144411, India \\ Email Id: bhardwajmandy.93@gmail.com \\ ORCID ID: https://orcid.org/0000-0003-4110-479X
}

Pushp Kumar (Corresponding Author)

School of Humanities, Social Sciences, and Management

Indian Institute of Technology Bhubaneswar, Odisha 752050, India

Email Id: pk27@iitbbs.ac.in

ORCID ID: https://orcid.org/0000-0002-2355-1871

\section{Siddharth Kumar}

School of Humanities, Social Sciences, and Management Indian Institute of Technology Bhubaneswar, Odisha 752050, India

Email Id: $\underline{\text { sk52@iitbbs.ac.in }}$

ORCID ID: https://orcid.org/0000-0002-5664-9314

\author{
Ashish Kumar \\ Department of Economics, School of Business \\ Lovely Professional University, Jalandhar, Punjab 144411, India \\ Email Id: ashishkumar151211@gmail.com
}

\begin{abstract}
The present study aims to examine the impact of climate change on wheat and rice yield of the Punjab state of India. Using district-level panel data from 1981 to 2017, the study employs fully modified ordinary least squares (FMOLS), dynamic ordinary least squares (DOLS), and pooed mean group (PMG) approaches. The Pedroni cointegration has established a long-run relationship of climate variables with rice and wheat crops. The results of FMOLS and DOLS show that minimum temperature has a positive effect on both wheat and rice, while maximum temperature is found to be negatively contributing to both the crops. Rainfall has a significant adverse effect on wheat yield. Seasonal rainfall has been detrimental to wheat and rice yield in the study period, indicating that excess rainfall proved counterproductive. Pooled mean group (PMG) model confirms the robustness of the results obtained by FMOLS and DOLS techniques. Moreover, Dumitrescu-Hurlin causality test has revealed a unidirectional causality running from minimum temperature, rainfall \& maximum temperature to rice and wheat yield. The findings of the study suggest that the government should invest in developing stress-tolerant varieties of wheat and rice, managing crop residuals to curb further environmental effect and sustain natural resources for ensuring food security.
\end{abstract}

Keywords: Punjab; Rice; Wheat; FMOLS; DOLS 


\title{
Impact of Climate Change on Rice and Wheat Yield in Punjab State of India: A
} District-Level Analysis

\begin{abstract}
The present study aims to examine the impact of climate change on wheat and rice yield of the Punjab state of India. Using district-level panel data from 1981 to 2017, the study employs fully modified ordinary least squares (FMOLS), dynamic ordinary least squares (DOLS), and pooed mean group (PMG) approaches. The Pedroni cointegration has established a long-run relationship of climate variables with rice and wheat crops. The results of FMOLS and DOLS show that minimum temperature has a positive effect on both wheat and rice, while maximum temperature is found to be negatively contributing to both the crops. Rainfall has a significant adverse effect on wheat yield. Seasonal rainfall has been detrimental to wheat and rice yield in the study period, indicating that excess rainfall proved counterproductive. Pooled mean group (PMG) model confirms the robustness of the results obtained by FMOLS and DOLS techniques. Moreover, Dumitrescu-Hurlin causality test has revealed a unidirectional causality running from minimum temperature, rainfall \& maximum temperature to rice and wheat yield. The findings of the study suggest that the government should invest in developing stress-tolerant varieties of wheat and rice, managing crop residuals to curb further environmental effect and sustain natural resources for ensuring food security.
\end{abstract}

Keywords: Punjab; Rice; Wheat; FMOLS; DOLS

\section{Introduction}

Agriculture plays a predominant role in developing an economy like India, where 50 per cent of the population depends on agriculture as a source of livelihood (Ministry of Agriculture, 2020). Besides the importance of food security and employment, agriculture also boosts the growth of other interlinked sectors, reduces rural poverty, and increases exports of agricultural commodities and foreign exchange (Tripathi et al., 2009; Vyas, 2003). Despite such favourable effects, the agriculture sector has grown on an average of 3.64 per cent after 1980 till 2019 (World Bank, 2020). During the pre-independence, it grew at 1 per cent, while it has grown at 2 per cent per annum in the post-independence era (Tripathi et al., 2009). Infrastructure, technological, and environmental concerns, as well as a lack of political commitment and policy implementation, could all be contributing factors to this stagnation (Kakarlapudi, 2012). On the other side, one of the biggest concerns today worldwide is climate change, which has threatened global stability. According to the 'Intergovernmental Panel on Climate Change', "a change in the state of the climate that can be identified (e.g., using statistical tests) by changes in the mean and/or the variability of its properties, and that persists for an extended period, typically decades or longer. It refers to any change in climate over time, whether due to natural variability or as a result of human activity" (IPCC, 2007).

Over the last centuries, human activities like deforestation for agricultural and industrial use, excess use of unrefined petrochemicals, and increased use of air conditioners have resulted in the rapid release of greenhouse gases (GHGs) (Morton 2007). It has played a significant role in the changing composition of the atmosphere, leading to global warming and change in the climate (Lobell et al., 2008). Thus, the climate change in the 1970s has attributed to warm in climate systems, disturbances in precipitation received, and frequent occurrence in otherwise rare extreme weather events, melting of ice in the arctic circle, an increase in oceanic temperature along 
with sea levels and weather extremes (Brown and Funk, 2008; Kotschi 2007). Extreme weather events (flooding $\&$ droughts) often lead to the obliteration of crops and food shortage (IPCC, 2018). As a result, both developed and developing countries are affected by climate change. India is known to be one of the developing nations that are most vulnerable to climate change owing to its immense reliance on agriculture for jobs. The dependency on climate variables like temperature and rainfall makes agriculture production very sensitive to changes in climate. In India, more than half the agricultural land and about 70-80 per cent of the total land is irrigated through groundwater (Falkenmark and Molden, 2008). Thus, rainfall received as predicted is considered a boon to the nation and extreme events a natural hazard. Approximately 80 per cent of the annual rainfall in India takes place between June and September during the South West Monsoon. A good amount of precipitation is very determinantal in maintaining sufficient groundwater levels. The changes in climatic condition result in variabilities in precipitation which in turn changes the groundwater levels. Since the agriculture sector is the most affected sector of the economy by climate, it is vital to study the relationship and the impacts of future climate change that might affect the existing pattern.

When Indian agriculture is considered, Punjab is found to be among the front-runner states in terms of total production and the producer of major food grains (wheat and rice). So, studying the regional conditions of the climate of Punjab is very crucial. Punjab falls under India's most fertile land regions; the climate is semi-arid tropical, mostly winter (November-March) and summer seasons (April-June). The precipitation usually begins from late June to early September. The achievement of the green revolution in Punjab leads to the state being turned into a food basket by the government to contribute highly to national food security. But over the years, the climate of the state has gone under some very noticeable climate changes. Rainfall has shown increasing trend and high variation in spatial-temporal pattern, increasing the chances of drought and flood in the economy. Along with rainfall, minimum temperature has also been observed to increase with no definitive increasing or decreasing change in maximum temperature. But the increasing humidity and cloudy weather have negatively impacted the crops, especially the rice crop in the region (Kaur et al., 2013). Whereas, on the one hand, a narrow study conducted only on one district has shown no such adverse effect of change in temperature on wheat productivity (Sidhu \& Kamal, 2013). While, on the other hand, the broader picture has shown opposite results, where rising temperature and falling rainfall led to a significant adverse effect on the production efficiency of wheat and rice crop in Punjab from 1986-2015 (Kumar and Sidana, 2019). In light of this, this paper aims to look into the effects of climate change on rice and wheat yields in Punjab from 1981 to 2017. The fully modified ordinary least square (FMOLS), dynamic ordinary least square (DOLS), and pooled mean group (PMG) econometric models are used in this paper. Dumitrescu-Hurlin (2012) panel granger causality is also used for granger causality among variables. The study contributed to the existing knowledge in the following ways. First, this will be a first-panel study in Punjab, which has used the panel of 12 districts of Punjab. Second, most of the cited studies in the literature use the average annual temperature as a proxy for climate change. But we have considered only crop season average temperature, which will contribute to the existing literature of Punjab. Third, we use robust econometrics methods, i.e., FMOLS, DOLS and PMG, in which we found similar results across models. Earlier studies use only a single model; they have not verified their finding with other models. The next section deals with the "Review of Literature" presenting the related studies. After that, the variables used in the study and the research methods have been discussed in the "Data and Methods" section. Using the methods, the results obtained have been deliberated in the "Results and Discussion" section followed by the "Conclusion and Policy Implications" of the study. 


\section{Review of Literature}

This section deals with a summary of the literature related to climate change and agricultural production. We have included those studies which directly or indirectly investigated the effects of climate change on wheat, rice, and cereal crops at regional, single country, and multiple countries levels. Table 1 provides the important results of the literature review.

\section{Insert [Table 1]}

All the above-reviewed studies have shown that climate change is affecting agriculture production either positively or negatively. Studies of Olayide et al. (2016), Chandio et al. (2020b), Loum \& Fogarassy (2015), Kaimakamis et al. (2013) are based on a single country. Asian country-based studies (Praveen \& Sharma, 2019; Baig et al., 2020; Janjua et al., 2014; Ahsan et al., 2020) and Punjab region-specific studies (Grover \& Upadhyay, 2014; Hundal \& Kaur, 2007; Kumar \& Sidana, 2019; Mahmood et al., 2012) have shown that rainfall and temperature are affecting rice, wheat and other crops positively and negatively depending upon when the extreme or scarce rainfall is received, variation in maximum and minimum temperature. Kumar et al. (2021), Kumar \& Sidana (2019); Appiah et al. (2018); Zaied \& Zouabi (2015) have looked into all of the concerns, including serial correlation, panel group-wise heteroscedasticity, and cross-sectional dependence. But there is a notable paucity of empirical research focusing specifically on analysing the impact of changing climate pattern on most cultivated crops in Punjab, i.e., wheat and rice. After 1980, due to the seasonal variation in climatic factors like maximum and minimum temperature, rainfall on crops. Most of the studies have only been limited to either a few districts or single districts of Punjab taking the average temperature at the place of seasonal maximum or minimum temperature. At last, a large period of time is considered while tackling all panel data problems for authentic regression analysis. With this motivation, the study aims to investigate the impact of climate change on wheat and rice yields in Punjab during 1981-2017. To overcome the methodological issues, FMOLS, DOLS and PMG models are employed in this study.

\section{Data and Methods}

\section{Data and Model Specification}

Given the importance of wheat and rice as major crops of Punjab in providing food security, we take the data for wheat and rice separately for the analysis. Our panel data covers 12 major wheat and rice producing districts of Punjab during the period of 1981-2017. Table 2 describes the variables, their symbols, units and their sources through which data have been collected. From the literature, maximum and minimum temperature along with rainfall have been identified as the key determinants of rice and wheat yield. The trends of these key dependent and independent variables have been shown in Figure 1-8. Apart from that, the production of these crops also depends on the cultivated area, which relates to how much area these crops are sown in. Therefore, based on these variables, the following model specifications are framed:

$R Y_{i t}=f\left(R M x T_{i t}, R M i T_{i t}, R P_{i t}, R A_{i t}\right)$

$$
\ln R Y_{i t}=\beta_{0}+\beta_{1} \ln R M x T_{i t}+\beta_{2} \ln R M i T_{i t}+\beta_{3} \ln R P_{i t}+\beta_{4} \ln R A_{i t}+u_{i t}
$$


Where $R Y$ : rice yield, $R M x T$ : the average maximum temperature during the rice harvesting season, RMiT: the average minimum temperature during the rice harvesting season, $R P$ : the average precipitation (rainfall) during the rice harvesting season, $R A$ : area cultivated for rice, $\beta$ : coefficients, $u$ : error term, subscript $i$ : the cross sections which are 12 districts of Punjab selected for the study and subscript $t$ : time which is 1981-2017 for the study.

$W Y_{i t}=f\left(W M x T_{i t}, W M i T_{i t}, W P_{i t}, W A_{i t}\right)$

$\ln W Y_{i t}=\beta_{0}+\beta_{1} \ln W M x T_{i t}+\beta_{2} \ln W M i T_{i t}+\beta_{3} \ln W P_{i t}+\beta_{4} W R A_{i t}+u_{i t}$

160

$y_{i, t}=\left(1-p_{i}\right) \alpha_{i}+p_{i} y_{i, t-1}+\varepsilon_{i t}$ the estimation of the models specified.

The equation for LLC is following:

The equation for IPS is following:

Where the null hypothesis is that $p=1$.

Where WY: wheat yield, WMxT: the average maximum temperature during the wheat harvesting season, WMiT: the average minimum temperature during the wheat harvesting season, WP: the average precipitation (rainfall) during the wheat harvesting season, $W A$ : area cultivated for wheat, $\beta$ : coefficients, $u$ : error term, subscript $i$ : the cross sections which are 12 districts of Punjab selected for the study and subscript $t$ : time which is 1981-2017 for the study. From the above-framed model specifications, we move on to the methodology that has been used for

Insert [Table 2]
Insert [Figure 1]
Insert [Figure 2]
Insert [Figure 3]
Insert [Figure 4]
Insert [Figure 5]
Insert [Figure 6]
Insert [Figure 7]
Insert [Figure 8]

\section{Panel Unit-Root Test and Cointegration Test}

Before estimating the impact of climate change on the main crops of Punjab, it is imperative to check the stationarity of the variables so as to avoid any biased results. For estimation, the first-generation unit-root test given by Levin, Lin and Chu (LLC), and Im, Pesaran and Shin (IPS) were used, which assume the statistical independence of each cross-sectional data series in the study (Barbieri, 2008).

$\Delta y_{i, t}=\phi_{i} y_{i, t-1}+\sum_{N=1}^{p_{i}} \psi_{i, N} \Delta y_{i, t-N}+\alpha_{m, i} \beta_{m, t}+\epsilon_{i, t}$

Where y refers to the variable being tested for unit root, $\Delta$ denotes the differentiated form of the variable, $\phi_{i}$ is less than zero for the non-existence of unit root against the null hypothesis of $\phi_{i} \geq 0$. 
The null hypothesis under the above methods has stated the existence of unit root (stationarity), while the alternative has shown non-stationarity in the panel data (Akpolat, 2014). If non-stationarity exists, then cointegration is estimated to get a consistent and efficient estimation. For cointegration, the Pedroni cointegration method is applied, which has developed seven different tests to determine the existence of panel cointegration.

The equation for Pedroni Cointegration is:

$Y_{i, t}=\alpha_{i}+\delta_{i} t+\beta_{1 i} X_{1 i, t}+\beta_{2 i} X_{2 i, t}+\cdots+\beta_{K i} X_{K i, t}+\mu_{i t}$

From the above-estimated equation, the residuals $\hat{\mu}_{i, t}$ are tested through the following equation:

$\Delta \hat{\mu}_{i, t}=p_{i} \Delta \hat{\mu}_{i, t-1}+\sum_{k=1}^{n} \phi_{i, k} \Delta \hat{\mu}_{i, t-k}+v_{i, t}$

There is a presence of cointegration when $p_{i}$ is significantly different from zero.

\section{FMOLS and DOLS Model}

Panel cointegration methods have evolved the long-run economic relationship between the variables often projected in economic theory. Thus, the long-run coefficients test whether the variables satisfy the theoretical restrictions or not (Mohapatra \& Gopalaswamy, 2016). After determining cointegration or long-run relationship, the direction and magnitude of the long-run relationship among variable can be quantified by applying the fully modified ordinary least square method (FMOLS) \& dynamic ordinary least square (DOLS) methods.

The equation for FMOLS and DOLS are:

$\hat{\beta}_{F M O L S}^{*}=N^{-1} \sum_{n=1}^{N} \hat{\beta}_{F M O L S, n}^{*}$

Here $\hat{\beta}_{F M O L S}^{*}$ represents FMOLS regression parameter applied in $\mathrm{n}$ countries.

$\hat{\beta}^{*}{ }_{D O L S}=N^{-1} \sum_{n=1}^{N} \hat{\beta}_{D O L S, n}^{*}$

Here $\hat{\beta}^{*}{ }_{D O L S}$ represents DOLS regression parameter applied to cross-sections $\mathrm{n}$.

The FMOLS is a non-parametric technique, and the DOLS is a parametric procedure used to eliminate the problems of serial correlation and endogeneity (Akpolat, 2014; Othman \& Masih, 2015). The applicability of these methods is subjected to the pre-conditions of unit root tests of all variables in the same order and the existence of cointegration among the independent variables (Othman \& Masih, 2015). Further, FMOLS is sensitive to simultaneous bias but adjusts the unit-specific fixed effects, short-run dynamics and give efficient and consistent estimation (Mohapatra \& Gopalaswamy, 2016). At the same time, DOLS is used by taking crosssectional leads of dependent variables and lagged values of explanatory variables to reduce endogeneity.

\section{Pooled Mean Group (PMG) Model}

After getting the coefficients with FMOLS \& DOLS, Pooled Mean Group (PMG) method is used to estimate both the short and long-run coefficients as it examines the existing heterogeneity present in the dynamic panel data (Tatoglu, 2011; Rafindadi, 2017). It becomes important so that in the long run, the impact of climate change on 
area $\&$ production of various crops is homogenous. In the short run, the different districts taken in the study might have shown heterogeneity in the area and production due to the availability of different requirements of water, fertility of the land, mechanisation etc. (Rafindadi, 2017). Further, PMG estimation supports the estimated coefficients of FMOLS \& DOLS by eliminating the problem of endogeneity with the inclusion of sufficient lag of all variables (Asteriou et al., 2020).

\section{Dumitrescu-Hurlin Panel Causality Tests}

After FMOLS, DOLS and PMG, Dumitrescu-Hurlin (2012) panel causality test has been used to identify the causality amongst the variables used in the study. Dumitrescu-Hurlin (2012) has given an advanced version of the Granger causality test where a homogenous non-causality hypothesis was tested, which implies there is no such causal link between two variables in all the cross-sections units (Ndoricimpa, 2014), whereas the alternative hypothesis shows that a causal relationship exists among the variables (Kumar et al., 2021). The test can be represented in the following equation:

$\mathrm{y}_{\mathrm{it}}=\alpha_{\mathrm{i}}+\sum_{\mathrm{i}=1}^{\mathrm{k}} \gamma_{\mathrm{i}}^{(\mathrm{k})} \mathrm{y}_{\mathrm{i}, \mathrm{t}-\mathrm{k}}+\sum_{\mathrm{i}=1}^{\mathrm{k}} \beta_{\mathrm{i}}^{(\mathrm{k})} \mathrm{x}_{\mathrm{i}, \mathrm{t}-\mathrm{k}}+\varepsilon_{\mathrm{it}}$

Where $\beta_{i}=\left(\beta_{i}^{(1)}, \beta_{i}^{(2)} \ldots, \beta_{i}^{(k)}\right) \alpha_{i}$ represents individual effects, which are supposed to be fixed in the time dimension, $\mathrm{k}$ denotes the lag orders and is assumed the same for all cross-sectional units, $\gamma_{\mathrm{i}}^{(\mathrm{k})}$ and $\beta_{\mathrm{i}}^{(\mathrm{k})}$, respectively, represent lag and slope parameters that differ across groups.

\section{Results and Discussion}

Table 3 and 4 presents the descriptive statistics for all the variables corresponding to wheat and rice from 19802017. As shown in the table, the highest variation is observed in rice yield and wheat yield in comparison to the other variables, i.e., 575.803 and 731.957, respectively. Further, all the variables under wheat and rice have shown more symmetrical distribution except the production of wheat and rice that have shown a movement slightly towards left tail and inclusion of some exceptional years high or less production. Besides the distribution of various variables, rice yield is showing a $28 \%$ association with minimum temperature, while wheat is observed to be $36 \%$ correlated with maximum temperature. The other variables have shown an association with the productivity of rice and wheat in the range of $4 \%$ to $-15 \%$.

$$
\begin{aligned}
& \text { Insert [Table 3] } \\
& \text { Insert [Table 4] } \\
& \text { Insert [Table 5] }
\end{aligned}
$$

In order to determine the long-run relationship among the variables, it is necessary to fulfil the pre-conditions of possessing unit root (non-stationarity) among all variables, either at level or at first difference. Table 5 has shown unit root tests by using Levin, Lin and Chu (LLC) \& Im, Pesaran and Shin (IPS) Tests. The benefit of estimating unit root by IPS over LLC is that, where the latter assumes homogeneity (independence among cross-section panel), the former assumes heterogeneity (dependency among cross-section panel) across the panel (Libanio, 2005). Thus, variables viz. RY, WY, RMxT, RMiT, WMiT, RP, WP, RA, are found to be stationary at the level and first difference among both the tests. While variables viz. WMxT and lnWA are stationary at the first 
difference in both LLC \& IPS. Thus, all variables are stationary, which states a long-run relationship among variables, and the independent variable can be regressed on the dependent variable without spurious regression.

$$
\text { Insert [Table 6] }
$$

Insert [Table 7]

Table 6 and 7 show cointegration estimation of wheat and rice crop with various climate variables in the long run. For cointegration, a robust $\&$ heterogenous Pedroni test is used, which gives seven different statistics. The estimation has shown that cointegration within the panel and between panel statistics is statistically significant at a one per cent level in both rice and wheat. However, some exceptional results have been observed under panel $\mathrm{v}$-statistics and group rho-statistics for rice and wheat where data failed to show any cointegration, which could be due to different time period $(\mathrm{T}$ ) and places that have caused different relationship among the variables (Chien et al., 2014). Otherwise, overall estimation has established the long-run relationship among various climate variables and the production of wheat and rice according to Pedroni's seven different tests (Ageliki et al., 2016; Neal, 2014)

\section{Impact on Rice Yield}

As the study has included different districts and a long time period, it increases the chance of autocorrelation \& heteroscedasticity. So, after determining cointegration \& avoiding spurious regression, DOLS and FMOLS cointegrating equation estimations have been used to estimate or quantify the long-run relationship among the variables (Othman, 2015). Panel FMOLS is a non-parametric test to control the problem of endogeneity and correlation that arise due to cross-section variables (Ramirez, 2006; Akpolat, 2014). In comparison, panel DOLS is a parametric test used to estimate long-run coefficients by preventing the trend in variables by specifications in regressors (Mitic et al., 2017; Akpolat, 2014).

\section{Insert [Table 8]}

Table 8 has shown FMOLS \& DOLS long-run estimations or the impact of various climatic variables described in Table 1 on the productivity of rice. The empirical estimations of FMOLS have presented that the coefficient of minimum temperature has shown a positive change in rice yield, which is statistically significant at $1 \%$ level. Additionally, a $1^{\circ} \mathrm{C}$ increase in temperature has increased rice yield by $2.309 \%$. The findings of the paper can be supported by various national, regional and international empirical estimations. As the countries possessing similar characteristics to India like Pakistan \& Bangladesh have shown that an increase in the minimum temperature in Pakistan has positively affected the rice yield due to the growth of crop at the replantation stage during the vegetation phase, and in Bangladesh, its impact is neutral on different varieties of rice (Abbas \& Mayo, 2021; Chowdhury \& Khan, 2015). Whereas in China, the exact opposite results can be observed where the minimum temperature has shown a negative impact on yield although insignificant, and it happens due to an increase in respiration loss during night time (Zhang et al., 2010). While in Punjab, the study has shown a positive non-significant effect of an increase in average temperature above normal (Hundal \& Kaur, 2007).

The coefficient of maximum temperature is found to be negatively affected the rice yield, where a $1{ }^{\circ} \mathrm{C}$ increase in maximum temperature decreased rice yield by $2.606 \%$. The findings of the same coefficient are supported by various studies done on Punjab. Grover \& Upadhya (2014) and Saseendran et al. (2000) has observed a negative 
impact of the increase in rice productivity due to a rise in the average temperature, enhanced due to an increase in the level of warming. Similarly, a district-level study conducted by Kumar \& Sidana (2019) has shown that maximum and minimum temperature has negatively impacted rice yield, but the negative effect of maximum temperature can be eliminated due to an assured irrigational facility in Punjab. The same conclusion has been observed by Zhang et al. (2010) that the maximum temperature leads to the falling of rice yield due to short crop duration.

299

300

301

302

303

304

305

306

307

308

309

310

311

312

313

314

315

316

317

318

319

320

321

322

323

324

325

326

327

328

329

330

The coefficient of rainfall is showing a negative impact on rice productivity at $10 \%$ level. It is contradicting to various studies which have shown a positive effect of increased rainfall on agricultural productivity (Kumar et al., 2021). Further, the negative impact can be observed due to an increase in rainfall during the ripening stage (Abbas \& Mayo, 2021). Due to heavy rainfall in the month of August in Meghalaya shows a significant and - $0.46 \%$ impact on rice (Dkhar et al., 2017) and an increase in rainfall from 5\% to $15 \%$ in the month of September-October has negatively impacted rice yield in Punjab (Mahmood et al., 2012).

Similarly, the coefficient of the land has a positive impact on rice productivity, where $1 \%$ increase in the land has improved the productivity by $0.223 \%$. A study conducted in China, the leading rice producer, has shown that an increase in average land size/plots will increase the technical efficiency in the long run (Tan et al., 2010). Further, a positive relationship can be seen between ownership of land and rice yield in India (Koirala, 2014) and land inequality suppressing the farmers to use resources and affecting rice productivity adversely (Prasanna et al., 2009). Additionally, the estimations of DOLS have analysed that $1 \%$ increase in minimum temperature brought a positive and significant change of $3.474 \%$ in rice. Further, maximum temperature and rainfall are affecting rice negatively by $3.87 \%$ and $0.034 \%$ but insignificantly. The reason for the negative impact might be due to a decrease in the number of plants at the ripening stage, tillering or stem elongation stage (Abbas \& Mayo, 2021) and heavy rainfall in the maturity stage (Mahmood et al., 2012).

\section{Impact on Wheat Yield}

Table 9 has given the estimations of FMOLS and DOLS on wheat as similar estimations have been done on rice yield. Estimating the effect of the dependent variable on the independent variable, the FMOLS estimator is used, which has shown that the minimum temperature coefficient is increasing wheat yield by $2.520 \%$, while an increase in maximum temperature depresses wheat yield by $2.012 \%$ due to $1^{\circ} \mathrm{C}$ change. Various studies have shown that the average increase in the temperature has deteriorated the wheat yield due to an increase in temperature at the grain-filling stage (Asseng, 2011). A low temperature and high radiation will positively impact wheat grain production (Amir, 1991), and wheat yield is adversely affected during the increase in temperature in the month of February \& March (Jha \& Tripathi, 2011). Besides, in lieu of increasing temperature and the absence of a proper irrigation facility, groundwater dependence leads to a sustainability crisis and depresses the wheat yield as well (Sudmeyer et al., 2016). Further, it becomes very important to understand that how and why the wheat yield is offsetting or improving under low or high temperature. Wiersma (2018) has written that daytime cooler temperature is positively increasing the yield, but the increasing temperature during tillering decreases the productivity of wheat by negatively affecting spikelets. Whereas Kleinjan (2021) has discussed that lower temperature is generally having low resistance towards lower temperature when it has already grown and at maturity stage, while high resistance towards lower temperature is at reproductive stage. 
332 The coefficient of rainfall is negatively determining the wheat yield at 5\%, which is empirically tested or discussed under various studies and discussion, because of change in rainfall intensity which is significantly correlated with the type of soil, i.e. sandy \& lower mineral at an early stage (Tataw et al., 2016), untimely rainfall triggered the quality. A decrease in rainfall in the vegetative stage and an increase in the reproductive stage reduce wheat production (Yu, 2013). Lastly, the coefficient of land is detrimental to wheat yield as it can be observed that with $1 \%$ change in the land would negatively impact the wheat yield by $0.164 \%$. Various reasons may lead to such situations, and supporting the estimation of the current study as land degradation is offsetting more than climate change (Raimondo et al., 2021). Further, a positive relationship can be seen between ownership of land and rice yield in India (Koirala, 2014) and land inequality suppressing the farmers to use resources and affecting rice productivity adversely (Prasanna et al., 2009).

Additionally, the estimations of DOLS have presented that $1 \%$ increase in minimum temperature brought a positive and significant change of $2.745 \%$ in the productivity of wheat. Further, maximum temperature, area and rainfall are affecting rice yield by $2.909 \%, 0.157 \%$ and $0.102 \%$ significantly at 5,10 and $1 \%$ level, respectively.

Table 10 and 11 have shown the short and long-run dynamics of change in the variable in the study on the productivity of rice and wheat. PMG is supporting the FMOLS, and it is preferred over DOLS due to its assumption of homogeneity in the long run and maintaining the property of heterogeneity in the short run. It helps us to show how an independent variable determines the dependent variable in the short and long run while tackling the problem of endogeneity and variable specific effects (Samargandi et al., 2014). Thus, the results of the PMG estimator have shown a similar impact in the long run as of FMOLS \& DOLS except for the variation in the minimum temperature that has brought an insignificant change in the rice yield. All other variables have similar significant positive and negative impact on the productivity of rice. On the contrary, change in area in the short run does not have any significant impact on rice productivity.

The short and long-run relationship of different variables in wheat productivity has shown similar results as in the FMOLS and DOLS. Here, all variables, in the long run, have the same negative and positive effect on yield. While, in the short run, change in production has a positive and significant impact on wheat productivity. The rest of the variables, i.e. change in the area, minimum and maximum temperature, caused an insignificant effect on the productivity of wheat. Meanwhile, comparing the impact of variation in the independent variables like minimum temperature, maximum temperature, area and production have shown a more vibrant effect on the productivity of rice and wheat than in the long run.

The Dumitrescu-Hurlin panel causality test is also used to investigate the causal relationship among variables. 
367 (Chishti et al., 2021). The results in Table 12 have shown a bi-directional causal relationship between rice and its corresponding variables, i.e., area to yield \& rainfall to minimum temperature. Similarly, rice yield to the maximum temperature, rice yield to rainfall, maximum to minimum temperature, rice area to rainfall $\&$ rice area to maximum temperature have shown unidirectional causality at $1 \%, 5$ and $10 \%$ level of significance, respectively. The results of Table 13 have shown a unidirectional causal relationship between wheat and various variables like yield to minimum temperature, maximum temperature to wheat yield, rainfall to yield, wheat area to wheat yield, maximum to minimum temperature, wheat rainfall to minimum temperature and maximum temperature at $1 \%$ level.

\section{Conclusion and Policy Implications}

The study aims to examine the impact of climatic variables on the major crops, i.e., rice and wheat, in the Punjab state of India during the time period 1981-2017. Pedroni cointegration technique has been used to identify the long-run relationship between climate variables and rice and wheat yields. The long-run association between the variables is tackled with FMOLS \& DOLS techniques are employed for empirical estimation, while the PMG model is used for robustness purpose. The estimated results have shown the long-run relationships between climatic factors as of Minimum Temperature, Maximum Temperature, Rainfall \& control variables, i.e. area under rice and wheat crops in Punjab. Further, FMOLS \& DOLS models have shown that minimum temperature and harvested area contribute positively to the yield of rice. On the contrary, the maximum temperature and rainfall have a deteriorating impact on rice productivity. In the case of the wheat crop, maximum temperature and rainfall are detrimental to wheat productivity in the study area during the time under consideration. However, the minimum temperature is the only variable that is observed to be enhancing the wheat yield. The results of the PMG model supports the findings of FMOLS and DOLS, which ensures the robustness of the estimated models. Dumitrescu-Hurlin causality test reveals a bidirectional causality between rice yield and harvested area of rice, while a unidirectional causality runs from the harvested area of wheat to wheat yield.

As shown above, most of the climatic factors except minimum temperature and control variable have a negative effect on rice and wheat. So, it is an alarming stage to address the issue of agricultural sustainability. Because if rainfall is affecting the yield adversely, either in the case of wheat or rice, then the concern for the government and policymakers is to follow adaptative and mitigation policies which will help farmers to sustain their income without affecting the sustainability of natural resources. Rainwater harvesting, creating awareness among farmers, broadening the view of extension department for various adaptative policies to combat the climate impact on wheat and rice (Mahmood et al., 2012). Meanwhile, to prevent the damage or death of plants at maturity stage or reproductive stage either by increase/decrease in minimum or maximum temperature on wheat and rice can be controlled by using water-saving (stress-tolerant varieties of seeds \& crop diversification), carbon management (managing the legumes and crop residual), knowledge or smart movement like (extension program and emphasis on research) can help to minimize the impact of climate change to some extent (Malhi et al., 2021). Therefore, the Punjab government should take appropriate policy measures to maintain the consistency of the largest shareholder in the food basket of the country after the green revolution and also to manage the water-led facility.

\section{Declaration:}


Ethics approval and consent to participate: Not applicable

Consent for publication: Not applicable

Availability of data and materials: Data will be made available upon request

407

Competing interests: We do not have any conflict of interest

Funding: There is no funding to report

Authors' contributions: Mandeep Bhardwaj and Pushp Kumar have done the Literature Review, Data Analysis and Results Reporting. Siddharth Kumar and Ashish Kumar have compiled the Introduction and Discussion of the Results. Pushp Kumar and Mandeep Bhardwaj have done the overall formatting of the paper. All authors have read and approved the manuscript.

Acknowledgements: Not Applicable

\section{References}

Abbas, S., \& Mayo, Z.A. (2021). Impact of temperature and rainfall on rice production in Punjab, Pakistan. Environ Dev Sustain, 23, 1706-1728. https://doi.org/10.1007/s10668-020-00647-8

Anagnostou, A., Kallioras, D., \& Petrakos, G. (2016). Integrating the Neighbors: A Dynamic Panel Analysis of the EU-ENP Countries' Trade Relations. Comparative Economic Studies, 58(1), 17-42. https://doi.org/10.1057/ces.2015.23

Ageliki, A., Dimitris, K. and George, P. (2016). Integrating the Neighbors: A Dynamic Panel Analysis of the

Ahsan, F., Chandio, A.A., \& Fang, W. (2020). Climate change impacts on cereal crops production in Pakistan: Evidence from cointegration analysis. International Journal of Climate Change Strategies and Management, 12(2), 257-269. https://doi.org/10.1108/IJCCSM-04-2019-0020

Akpolat, A. G. (2014). The Long-Term Impact of Human Capital Investment on GDP: A Panel Cointegrated Regression Analysis. Economics Research International. 1(10). https://doi.org/10.1155/2014/646518

Amir, J., \& Sinclair, T. R. (1991). A model of the temperature and solar-radiation effects on spring wheat growth and yield. Field Crops Research, 28(1-2), 47-58. https://doi:10.1016/0378-4290(91)90073-5

Appiah, K., Du, J. \& Poku, J. (2018). Causal relationship between agricultural production and carbon dioxide emissions in selected emerging economies. Environmental Science and Pollution Research, 25, 2476424777. https://doi.org/10.1007/s11356-018-2523-Z

Asseng, S., Foster, I. \& Turner, N. C. (2011). The impact of temperature variability on wheat yields. Glob. Change Biol. 17, 997-1012. https://doi.org/10.1111/j.1365-2486.2010.02262.x 
Asteriou, D., Pilbeam, K. \& Pratiwi, C. E. (2021). Public debt and economic growth: panel data evidence for Asian countries. J Econ Finan. 45, 270-287 https://doi.org/10.1007/s12197-020-09515-7

Attiaoui, I., \& Boufateh, T. (2019). Impacts of climate change on cereal farming in Tunisia: a panel ARDLPMG approach. Environ Sci Pollut Res, 26, 13334-13345. https://doi.org/10.1007/s11356-019-04867-y

Baig, I. A., Ahmed, F., Salam, M. A., \& Khan, S. M. (2020). An assessment of climate change and crop productivity in India: a multivariate cointegration framework. TEST Engineering \& Management, 83, $3438-3452$.

Barbieri, L. (2008). Panel Cointegration Tests: A Survey. Rivista Internazionale Di Scienze Sociali, 116(1), 336.

Brown, M. E., \& Funk, C. C. (2008). Food security under climate change. Science, 319(5863), 580-581. https://doi.org $10.1126 /$ science. 1154102

Chandio, A.A., Jiang, Y., Rehman, A. and Rauf, A. (2020a). Short and long-run impacts of climate change on agriculture: an empirical evidence from China. International Journal of Climate Change Strategies and Management, 12(2), 201-221. https://doi.org/10.1108/IJCCSM-05-2019-0026

Chandio, A.A., Ozturk, I., \& Akram, W. (2020b). Empirical analysis of climate change factors affecting cereal yield: evidence from Turkey. Environ Sci Pollut Res. 27, 11944-11957. https://doi.org/10.1007/s11356$\underline{020-07739-y}$

Chien, M., Lee, C. \& Cai, S. (2014). A Panel Cointegration Analysis for Macroeconomic Determinants of International Housing Market. World Academy of Science, Engineering and Technology. International Journal of Economics and Management Engineering, 8(7), 2066- 2073. https://doi.org/10.5281/zenodo.1093548

Chishti, M. Z., Ahmad, M., Rehman, A., \& Khan, M. K. (2021). Mitigations pathways towards sustainable development: assessing the influence of fiscal and monetary policies on carbon emissions in BRICS economies. Journal of Cleaner Production, 292, 126035. https://doi.org/10.1016/j.jclepro.2021.126035

Chowdhury, I. U. A., \& Khan, M. A. E. (2015). The impact of climate change on rice yield in Bangladesh: a time series analysis. Russian Journal of Agricultural and Socio-Economic Sciences, 40(4).

Dkhar, D.K., Feroze, S.M., Singh, R. (2017). Effect of Rainfall Variability on Rice Yield in North Eastern Hills of India: A Case Study. Agricultural Research, 6, 341-346. https://doi.org/10.1007/s40003-017-0276-4

Dumitrescu, E.I. \& Hurlin, C. (2012). Testing for Granger non-causality in heterogeneous panels. Economic Modelling, 29(4), 1450-1460. http://doi.org/10.1016/j.econmod.2012.02.014

Dumrul, Y., Kilicarslan, Z., (2017). Economic impacts of climate change on agriculture: empirical evidence from ARDL approach for Turkey. Journal of Business, Economics and Finance, 6(4), 336-347. http://doi.org/10.17261/Pressacademia.2017.766. 
Falkenmark, M., \& Molden, D. (2008). Wake up to realities of river basin closure. International journal of water resources development, 24(2), 201-215. https://doi.org/10.1080/07900620701723570

Grover, D. K. \& Upadhya, D. (2014). Changing Climate Pattern and Its Impact on Paddy Productivity in Ludhiana District of Punjab. Indian Journal of Agricultural Economics. 69(1), 1-13.

Guntukula, R. (2019). Assessing the impact of climate change on Indian agriculture: Evidence from major crop yields. Journal of Public Affairs. 20(1), 1-7. https://doi.org/10.1002/pa.204

Guntukula, R., \& Goyari, P. (2020). The impact of climate change on maize yields and its variability in Telangana, India: A panel approach study. Journal of Public Affairs. https://doi.org/10.1002/pa.2088

Hundal, S., \& Kaur P. (2007). Climatic variability and its impact on cereal productivity in Indian Punjab. Current Science, 92(4), 506-512.

IPCC, Climate Change (2007). The physical science basis. Contribution of working group I to the fourth assessment report of the Intergovernmental Panel on Climate Change. Cambridge University Press, Cambridge, United Kingdom and New York, NY, USA, 996, 2007.

Intergovernmental Panel on Climate Change (2018). Global Warming of $1.5^{\circ} \mathrm{C}$ : An IPCC Special Report on the Impacts of Global Warming of $1.5^{\circ} \mathrm{C}$ Above Pre-industrial Levels and Related Global Greenhouse Gas Emission Pathways, in the Context of Strengthening the Global Response to the Threat of Climate Change, Sustainable Development, and Efforts to Eradicate Poverty.

Janjua, P. Z., Samad, G., \& Khan, N. (2014). Climate Change and Wheat Production in Pakistan: An Autoregressive Distributed Lag Approach. NJAS - Wageningen Journal of Life Sciences, 68, 13-19. https://doi:10.1016/j.njas.2013.11.002

Jha, B. \& Tripathi, A. (2011). Isn't Climate Change Affecting Wheat Productivity in India? Indian Journal of Agricultural Economics, 66(3), 1-12.

Kaimakamis, I., Aggelopoulos, S., \& Pavloudi, A. (2013). Agricultural Production \& Climate Changes. A Case of Greece. Journal of Environmental Protection and Ecology. 14(2), 693-698.

Kakarlapudi, K. K. (2012). Agricultural Growth Deceleration in India: An Enquiry into Possible Explanations. Journal of Regional Development and Planning, 1(1), 25-40. https://mpra.ub.unimuenchen.de/id/eprint/35865

Kaur. P., Sandhu, S.S., Simarnjit \& Gill, K.K. (2013). Climate change- Punjab Scenario. AICRPAM, School of climate change and agricultural Meteorology, Punjab Agriculture, Ludhiana. 1-16.

Kleinjan, J. (2021). Low Temperature Effects on Winter Wheat. Retrieved from: https://extension.sdstate.edu/low-temperature-effects-winter-wheat

Koirala, K. H., Mishra, A. K. \& Mohanty, S. (2014). Impact of Land Ownership on Productivity and Efficiency of Rice Farmers: A Simulated Maximum Likelihood Approach. Minneapolis, Minnesota 170608, Agricultural and Applied Economics Association. 
Kotschi, J. (2007). Agricultural Biodiversity Is Essential for Adapting to Climate Change. GAIA-Ecological Perspectives for Science and Society, 16, 98-101. https://doi.org/10.14512/gaia.16.2.8

Kumar, S. \& Sidana, B.K. (2019). Impact of climate change on the productivity of rice and wheat crops in Punjab. Economic and Political Weekly, 54 (46), 38-46.

Kumar, P., Sahu, N. C., Kumar, S., \& Ansari, M. A. (2021). Impact of climate change on cereal production: evidence from lower-middle-income countries. Environmental Science and Pollution Research, 1-15. https://doi.org/10.1007/s11356-021-14373-9

Libanio, G. A. (2005). Unit roots in macroeconomic time series: theory, implications, and evidence. Nova Economia, Economics Department, Universidade Federal de Minas Gerais 15(3), 145-176.

Lobell, D. B., Burke, M. B., Tebaldi, C., Mastrandrea, M. D., Falcon, W. P., \& Naylor, R. L. (2008). Prioritizing climate change adaptation needs for food security in 2030. Science, 319(5863), 607-610.

Loum, A., \& Fogarassy, C. (2015). The effects of climate change on cereals yield of production and food security in Gambia. Applied Studies in Agribusiness and Commerce. 9(4), 83-92. https://doi.org/10.19041/APSTRACT/2015/4/11

Mahmood N., Ahmad B., Hassan S., \& Bakhsh K. (2012). Impact of temperature and precipitation on rice productivity in rice-wheat cropping system of Punjab Province. J Anim Plant Sci 22(4), 993-997.

Malhi, G.S., Kaur, M., Kaushik, P. (2021). Impact of Climate Change on Agriculture and Its Mitigation Strategies: A Review. Sustainability, 13, 1318. https://doi.org/10.3390/su13031318

Ministry of Agriculture \& Farmers' Welfare, (2020). Annual Report, 2019-20. https://agricoop.nic.in/sites/default/files/ACFW\%20English\%20\%20Annual\%20Report\%202019-20.pdf.

Mitic, P. \& Ivanovic, O.M. \& Zdravkovic, A, (2017). A Cointegration Analysis of Real GDP and $\mathrm{CO}_{2}$ Emissions in Transitional Countries. Sustainability, 9(4), 1-18.

Mohapatra, L., \& Gopalaswamy, A. (2016). FDI, Domestic Investment And 2008 Financial Crisis: Evidence from Emerging Nations. The Journal of Developing Areas, 50(6), 277-289. https://www.jstor.org/stable/26415666

Morton, J. F. (2007). The impact of climate change on smallholder and subsistence agriculture. Proceedings of the national academy of sciences, 104(50), 19680-19685.

Ndoricimpa, A. (2014). Heterogeneous Panel Causality Between Exports and Growth in COMESA Countries. The Journal of Developing Areas, 48(4), 349-361.

Neal, T. (2014). Panel Cointegration Analysis with Xtpedroni. The Stata Journal, 14(3), 684692. https://doi.org/10.1177/1536867X1401400312

Olayide, O. E., Tetteh, I. K., \& Popoola, L. (2016). Differential impacts of rainfall and irrigation on agricultural production in Nigeria: Any lessons for climate-smart agriculture? Agricultural Water Management, 178, 30-36. https://doi:10.1016/j.agwat.2016.08.034 
Othman, A. N. \& Masih, M. (2015). Do profit and loss sharing (PLS) deposits also affect PLS financing? Evidence from Malaysia based on DOLS, FMOLS and system GMM techniques. MPRA Paper 65224, University Library of Munich, Germany.

Peng, S., Huang, J., Sheehy, J. E., Laza, R. C., Visperas, R. M., Zhong, X., Centeno, G. S., Khush, G. S., \& Cassman, K. G. (2004). Rice yields decline with higher night temperature from global warming. Proceedings of the National Academy of Sciences of the United States of America, 101(27), 9971-9975. https://doi.org/10.1073/pnas.0403720101

Prasanna, P. A., Kumar, S., \& Singh, A. (2009). Rice Production in India-Implications of Land Inequity and Market Imperfections1. Agricultural Economics Research Review, 22(conf), 431-442.

Praveen, B., \& Sharma, P. (2019a). Climate Change and its impacts on Indian agriculture: An Econometric analysis. Journal of Public Affairs. https://doi:10.1002/pa.1972

Praveen, B., \& Sharma, P. (2019b). Climate variability and its impacts on agriculture production and future prediction using autoregressive integrated moving average method (ARIMA). Journal of Public Affairs. https://doi:10.1002/pa.2016

Rafindadi, A. A., \& Ozturk, I. (2017). Dynamic Effects of Financial Development, Trade Openness and Economic Growth on Energy Consumption: Evidence from South Africa. International Journal of Energy Economics and Policy, 7(3),74-85.

Raimondo, M., Nazzaro, C., Marotta, G., \& Caracciolo, F. (2021). Land degradation and climate change: Global impact on wheat yields. Land Degradation \& Development,32(1), 387-398. https://doi.org/10.1002/ldr.3699

Ramirez, M. D., (2006). A Panel Unit Root and Panel Cointegration Test of the Complementarity Hypothesis in the Mexican Case, 1960-2001. Center Discussion Papers 28402, Yale University, Economic Growth Center. https://10.22004/ag.econ.28402

Samargandi, N., Fidrmuc, J., \& Ghosh, S., (2014). Financial development and economic growth in an oil-rich economy: The case of Saudi Arabia. Economic Modelling. 43(C), 267-278. https://10.1016/j.econmod.2014.07.042

Sarker, M.A.R, Khorshed, A. \& Jeff, G. (2014). Assessing the effects of climate change on rice yields: An econometric investigation using Bangladeshi panel data. Economic Analysis and Policy. 44(4), 405-416. https://doi:org/10.1016/j.eap.2014.11.004

Saseendran, S.A., Singh, K.K., Rathore, L.S. (2000). Effects of Climate Change on Rice Production in the Tropical Humid Climate of Kerala, India. Climatic Change, 44, 495-514 https://doi.org/10.1023/A:1005542414134

Sidhu, R. S., \& Kamal, V. (2013). Climate change and wheat yields in Punjab: the impact of rise in temperature. Agricultural Situation in India, 69(10), 29-32. 
Sudmeyer. R, Edward. A, Fazakerley. V, Simpkin. L \& Foster, I. (2016). Climate change: impacts and adaptation for agriculture in Western Australia. Bulletin 4870, Department of Agriculture and Food, Western Australia, Perth.

Tripathi, Amarnath and Prasad, A. R. (2009). Agricultural Development in India since Independence: A Study on Progress, Performance, and Determinants. Journal of Emerging Knowledge on Emerging Markets, 1, $63-$ 92. DOI: https://doi:org/10.7885/1946-651X.1007

Tan, S., Heerink, N., Kuyvenhoven, A., Qu, F. (2010). Impact of land fragmentation on rice producers' technical efficiency in South-East China. Wagening J. Life Sci. 57, 117-123.

Tataw, J.T., Baier, F., Krottenthaler, F. (2016). Climate change induced rainfall patterns affect wheat productivity and agroecosystem functioning dependent on soil types. Ecol Res, 31, 203-212. https://doi.org/10.1007/s11284-015-1328-5

Tatoglu, F. (2011). The long and short run effects between unemployment and economic growth in Europe. Doğuş Üniversitesi Dergisi, 12(1), 99-113.

Vyankatrao, N.K. (2017). Impact of climate change on agricultural production in India: effect on rice productivity. Bioscience Discovery, 8(4), 897-914.

Vyas, V.S. (2003), India's Agrarian Structure, Economic Policies and Sustainable Development: Variations on a Theme, Academic Foundation, New Delhi.

Wiersma, J. (2018). University of Minnesota Extension. Retrieved from https://extension.umn.edu/growingsmall-grains/how-high-temperatures-affect-wheat-yield-potential

World Bank. (2020, Sep). Agriculture and Food. https://www.worldbank.org/en/topic/agriculture/overview.

Yu, Q., Li, L., Luo, Q., Eamus, D., Xu, S., Chen, C., ... Nielsen, D. C. (2013). Year patterns of climate impact on wheat yields. International Journal of Climatology, 34(2), 518-528. https://doi.org/10.1002/joc.3704

Zaied, Y., \& Zouabi, O. (2015). Climate change impacts on agriculture: A panel cointegration approach and application to Tunisia. https://mpra.ub.uni-muenchen.de/id/eprint/64711

Zhai, S., Song, G., Qin, Y, \& Ye. X., Lee, J. (2017). Modeling the impacts of climate change and technical progress on the wheat yield in inland China: An autoregressive distributed lag approach. PLoS ONE, 12(9): e0184474. https://doi.org/10.1371/journal.pone.0184474

Zhang, T., Zhu, J., \& Wassmann, R. (2010). Responses of rice yields to recent climate change in China: An empirical assessment based on long-term observations at different spatial scales (1981-2005). Agricultural and Forest Meteorology, 150, 1128-1137. https://doi.org/10.1016/j.agrformet.2010.04.013 


\section{List of Tables}

Table 1. Summary of Relevant Studies on Climate Change and Agricultural Production

\begin{tabular}{|c|c|c|c|c|}
\hline Author(s) & Time & Country (ies) & Econometric model (s) & Results \\
\hline Olayide et al. (2016) & $1970-2012$ & Nigeria & Descriptive analyses & Rainfall $=>+$ but insignificant on agriculture \\
\hline $\begin{array}{l}\text { Zaied \& Zouabi } \\
\text { (2015) }\end{array}$ & $1980-2012$ & Tunisia & FMOLS, Panel Cointegration & $\begin{array}{l}\text { Temperature }=>\text { - on agriculture } \\
\text { Rainfall }=>\text { - on agriculture, }\end{array}$ \\
\hline $\begin{array}{l}\text { Dumrul \& Kilicarslan } \\
\text { (2017) }\end{array}$ & $1961-2013$ & Turkey & ARDL & $\begin{array}{l}\text { Rainfall }=>+ \text { ve on agriculture } \\
\text { Temperature }=>\text {-ve on agriculture }\end{array}$ \\
\hline Vyankatrao (2017) & $1991-2016$ & India & Crop Simulation model & Temperature $=>-$ on rice yield \\
\hline Sarker et al. (2014) & $1972-2009$ & Bangladesh & pope production function & Maximum temperature $=>+$ on rice yield \\
\hline Zhang et al. (2010) & $1980-2010$ & China & Regression Model & Temperature $=>-$ on rice yield \\
\hline $\begin{array}{l}\text { Kaimakamis et al. } \\
\text { (2013) }\end{array}$ & $1977-2007$ & Greece & Multiple linear regression & $\begin{array}{l}\text { Temperature }=>\text { - but insignificant on agriculture } \\
\text { Rainfall => - but insignificant on agriculture }\end{array}$ \\
\hline $\begin{array}{l}\text { Loum \& Fogarassy } \\
(2015)\end{array}$ & $1960-2013$ & Gambia & $\begin{array}{l}\text { Just and Pope modified } \\
\text { Ricardian production functions }\end{array}$ & Rainfall, Temperature $=>$ - on cereals yield \\
\hline $\begin{array}{l}\text { Praveen \& Sharma } \\
\text { (2019a) }\end{array}$ & $1967-2016$ & India & Multiple regression analysis & $\begin{array}{l}\text { Temperature }=>- \text { on maize and wheat Rainfall }=>+ \text { but } \\
\text { insignificant on maize and wheat }\end{array}$ \\
\hline $\begin{array}{l}\text { Praveen \& Sharma } \\
(2019 b)\end{array}$ & $1967-2016$ & India & ARIMA & Temperature $=>-$ on wheat and rice production \\
\hline $\begin{array}{l}\text { Guntukula \& Goyari } \\
\text { (2019) }\end{array}$ & $1956-2015$ & Telangana, India & FGLS & $\begin{array}{l}\text { Minimum temperature }=>- \text { on maize yield } \\
\text { Maximum temperature, rainfall }=>+ \text { on maize but } \\
\text { insignificant }\end{array}$ \\
\hline
\end{tabular}




\begin{tabular}{|c|c|c|c|c|}
\hline Guntukula (2019) & $1961-2017$ & India & Regression & $\begin{array}{l}\text { Rainfall => - on food crops except pulses, + on non-food } \\
\text { crops } \\
\text { Maximum temperature => on food and non-food crops } \\
\text { except rice } \\
\text { Minimum temperature => - on non-food crops, + on food } \\
\text { crops. }\end{array}$ \\
\hline Chandio et al. (2020a) & $1968-2014$ & Turkey & ARDL, Granger Causality & $\begin{array}{l}\text { Temperature }=>\text { - effect on cereal yield } \\
\text { Rainfall: + on cereal yield }\end{array}$ \\
\hline $\begin{array}{l}\text { Attiaoui \& Boufateh } \\
\text { (2019) }\end{array}$ & $1975-2014$ & Tunisia & ARDL, Granger Causality & $\begin{array}{l}\text { Rainfall }=>- \text { on cereal yield } \\
\text { Temperature }=>+ \text { on cereal yield }\end{array}$ \\
\hline Abbas \& Mayo (2020) & 1981-2017 & Punjab, Pakistan & $\begin{array}{l}\text { Cobb-Douglas production } \\
\text { function }\end{array}$ & $\begin{array}{l}\text { Maximum temperature }=>- \text { on rice yield } \\
\text { Minimum temperature }=>+ \text { on rice yield } \\
\text { Rainfall }=>+ \text { on rice yield }\end{array}$ \\
\hline Peng et al. (2004) & 1979-2003 & Philippines & Simulation method & Minimum temperature $=>-$ on rice yield \\
\hline Baig et al. (2020) & $1990-2017$ & India & ARDL & $\begin{array}{l}\text { Maximum temperature }=>+ \text { on all crops except for wheat } \\
\text { Minimum temperature }=>+ \text { on cereal yield Temperature }=>+ \\
\text { on wheat and cereal yield, - on rice yield } \\
\text { Rainfall }=>\text { - on cereals yield, +ve on wheat yield }\end{array}$ \\
\hline Ahsan et al. (2020) & $1971-2014$ & Pakistan & ARDL & $\begin{array}{l}\mathrm{CO}_{2} \text { emissions, cultivated area and }=>+ \text { on Cereals } \\
\text { Production }\end{array}$ \\
\hline Chandio et al. (2020b) & $1982-2014$ & China & ARDL, Johansen Cointegration & $\begin{array}{l}\text { Temperature, Rainfall }=>\text { - on agriculture. } \\
\text { Land => + on agriculture }\end{array}$ \\
\hline Zhai et al. (2017) & 1970-2014 & China & ARDL & $\begin{array}{l}\text { Rainfall => - on wheat yield } \\
\text { Land Size }=>+ \text { on wheat yield } \\
\text { Temperature => - but insignificant on wheat yield }\end{array}$ \\
\hline Janjua et al. (2014) & $1960-2009$ & Pakistan & ARDL & $\begin{array}{l}\text { Temperature }=>+ \text { but insignificant on wheat yield } \\
\text { Rainfall }=>+ \text { but insignificant on wheat yield }\end{array}$ \\
\hline
\end{tabular}




\begin{tabular}{|c|c|c|c|c|}
\hline $\begin{array}{l}\text { Grover \& Upadhyay } \\
\text { (2014) }\end{array}$ & $1972-2010$ & $\begin{array}{l}\text { (Ludhiana District) } \\
\text { Punjab }\end{array}$ & $\begin{array}{l}\text { Cobb-Douglas production } \\
\text { function }\end{array}$ & $\begin{array}{l}\text { Maximum temperature }=>\text { - on paddy yield } \\
\text { Minimum temperature, Rainfall => + on paddy yield }\end{array}$ \\
\hline Hundal \& Kaur (2007) & $1970-199$ & Punjab & CERES models & $\begin{array}{l}\text { Minimum and maximum temperature }=>\text { - on paddy, wheat } \\
\text { yield }\end{array}$ \\
\hline $\begin{array}{l}\text { Kumar \& Sidana } \\
(2019)\end{array}$ & 1986-2015 & Punjab & Fixed effect regression & $\begin{array}{l}\text { Temperature => - on rice } \& \text { wheat yield } \\
\text { Rainfall => - on wheat yield }\end{array}$ \\
\hline Mahmood et al. (2012) & $1978-2007$ & Punjab & $\begin{array}{l}\text { Cobb-Douglas production } \\
\text { function }\end{array}$ & Rainfall $=>-$ on rice yield \\
\hline Kumar et al. (2021) & $1971-2016$ & $\begin{array}{l}\text { Lower-Middle-Income } \\
\text { Countries }\end{array}$ & $\begin{array}{l}\text { FGLS, FMOLS, DOLS, and } \\
\text { Driscoll-Kraay standard } \\
\text { regression }\end{array}$ & $\begin{array}{l}\text { Temperature }=>\text { - cereals production } \\
\text { Rainfall }=>+ \text { cereals production }\end{array}$ \\
\hline
\end{tabular}

Note: = >: unidirectional relationship, (+): positive effect and (-): negative effect, PMG: pool mean group, FGLS: feasible generalized least square, ARDL: autoregressive distributed lag, DOLS: Dynamic Ordinary Least Square and FMOLS: Fully Modified Ordinary Least Square, LLC: Levin-Lin-Chu Unit-root test, IPS- Im-Pesaran-Shin Unit-root test 
Table 2. Variables Description

\begin{tabular}{|l|l|l|l|}
\hline Variables & Symbol & Unit & Source \\
\hline Rice Yield & RY & hg/ha & $\begin{array}{l}\text { Food and Agriculture } \\
\text { Organisation (FAO) }\end{array}$ \\
\hline Wheat Yield & WY & hg/ha & FAO \\
\hline Rice Season Average Maximum Temperature & RMxT & $\begin{array}{l}\text { Degree } \\
\text { Celsius }\end{array}$ & $\begin{array}{l}\text { National Aeronautics and } \\
\text { Space Administration } \\
\text { (NASA) Climate Portal }\end{array}$ \\
\hline Rice Season Average Minimum Temperature & RMiT & $\begin{array}{l}\text { Degree } \\
\text { Celsius }\end{array}$ & NASA Climate Portal \\
\hline Wheat Season Average Maximum Temperature & WMxT & $\begin{array}{l}\text { Degree } \\
\text { Celsius }\end{array}$ & NASA Climate Portal \\
\hline Wheat Season Average Minimum Temperature & WMiT & $\begin{array}{l}\text { Degree } \\
\text { Celsius }\end{array}$ & NASA Climate Portal \\
\hline Rice Season Average Annual Rainfall & RP & mm & NASA Climate Portal \\
\hline Wheat Season Average Annual Rainfall & WP & mm & NASA Climate Portal \\
\hline Rice Cultivated Area & RA & ha & FAO \\
\hline Wheat Cultivated Area & WA & ha & FAO \\
\hline
\end{tabular}

Table 3. Descriptive Statistics and Correlation Matrix for Rice Crop

\begin{tabular}{|c|c|c|c|c|c|}
\hline & RY & RMxT & RMiT & RA & $\mathrm{RP}$ \\
\hline Mean & 3459.619 & 38.328 & 26.882 & 158.225 & 114.334 \\
\hline Median & 3456.500 & 38.620 & 26.955 & 158.500 & 107.401 \\
\hline Maximum & 4873.000 & 43.345 & 29.560 & 367.000 & 298.578 \\
\hline Minimum & 1593.000 & 30.808 & 23.488 & 8.000 & 29.015 \\
\hline Std. Dev. & 575.803 & 2.143 & 1.217 & 86.719 & 45.750 \\
\hline Skewness & -0.024 & -0.456 & -0.359 & 0.216 & 0.814 \\
\hline Kurtosis & 2.961 & 3.158 & 2.650 & 2.053 & 3.929 \\
\hline \multirow[t]{2}{*}{ Observations } & 444 & 444 & 444 & 444 & 444 \\
\hline & $\ln R Y$ & $\ln R M x T$ & $\ln \mathrm{RMiT}$ & $\ln \mathrm{RA}$ & $\operatorname{lnRP}$ \\
\hline $\ln \mathrm{RY}$ & 1.000 & 0.049 & 0.263 & 0.135 & -0.033 \\
\hline $\operatorname{lnRMXT}$ & 0.049 & 1.000 & 0.892 & 0.288 & -0.892 \\
\hline lnRMIT & 0.263 & 0.892 & 1.000 & 0.377 & -0.749 \\
\hline $\ln R A$ & 0.135 & 0.288 & 0.377 & 1.000 & -0.126 \\
\hline $\operatorname{lnRP}$ & -0.033 & -0.892 & -0.749 & -0.126 & 1.000 \\
\hline
\end{tabular}

5 Table 4. Descriptive Statistics and Correlation Matrix for Wheat Crop

\begin{tabular}{|l|c|c|c|c|c|}
\hline & WY & WMiT & WMxT & WA & WP \\
\hline Mean & 3963.601 & 10.729 & 25.360 & 228.624 & 19.000 \\
\hline Median & 4059.500 & 10.784 & 25.413 & 226.000 & 15.457 \\
\hline Maximum & 6651.000 & 12.538 & 27.928 & 422.000 & 93.444 \\
\hline Minimum & 1998.000 & 8.898 & 20.828 & 23.000 & 2.198 \\
\hline Std. Dev. & 731.957 & 0.710 & 1.421 & 100.394 & 13.674 \\
\hline Skewness & -0.288 & -0.121 & -0.458 & 0.169 & 1.643 \\
\hline Kurtosis & 2.918 & 2.325 & 2.621 & 1.945 & 6.720 \\
\hline Observations & 444 & 444 & 444 & 444 & 444 \\
\hline
\end{tabular}




\begin{tabular}{|l|c|c|c|c|c|}
\hline & $\ln W Y$ & $\ln W M x T$ & $\operatorname{lnWMiT}$ & $\ln W A$ & $\ln W P$ \\
\hline $\ln W Y$ & 1.000 & 0.360 & 0.280 & 0.111 & -0.159 \\
\hline $\ln W M x T$ & 0.360 & 1.000 & 0.373 & 0.365 & -0.663 \\
\hline $\ln W M i T$ & 0.280 & 0.373 & 1.000 & -0.081 & -0.191 \\
\hline $\ln W A$ & 0.111 & 0.365 & -0.081 & 1.000 & -0.126 \\
\hline $\ln W P$ & -0.159 & -0.663 & -0.191 & -0.126 & 1.000 \\
\hline
\end{tabular}

6

$7 \quad$ Table 5. Unit Root Test Results

\begin{tabular}{|l|c|c|c|c|}
\hline & \multicolumn{2}{|c|}{ LLC } & \multicolumn{2}{c|}{ IPS } \\
\hline Variables & At Level & At first Difference & At Level & At first Difference \\
\hline $\operatorname{lnRY}$ & $-3.408^{* * *}$ & $-12.876^{* * *}$ & $-4.298^{* * *}$ & $-17.460^{* * *}$ \\
\hline $\operatorname{lnRMxT}$ & $-7.486^{* * *}$ & $-15.268^{* * *}$ & $-5.994^{* * *}$ & $-18.866^{* * *}$ \\
\hline $\operatorname{lnRMiT}$ & $-8.298^{* * *}$ & $-16.041^{* * *}$ & $-6.751^{* * *}$ & $-19.501 * * *$ \\
\hline $\operatorname{lnRA}$ & $-4.333^{* * *}$ & $-10.884 * * *$ & $-2.341 * * *$ & $-9.608 * * *$ \\
\hline $\operatorname{lnRP}$ & $-6.742^{* * *}$ & $-14.522^{* * *}$ & $-6.742^{* * *}$ & $-20.742^{* * *}$ \\
\hline $\ln \mathrm{WY}$ & $-2.243^{* *}$ & $-9.233^{* * *}$ & $-4.373^{* * *}$ & $-16.907 * * *$ \\
\hline $\ln \mathrm{WMxT}$ & 2.244 & $-6.551^{* * *}$ & $-8.532^{* * *}$ & $-19.758^{* * *}$ \\
\hline $\ln \mathrm{WMiT}$ & $-1.437 *$ & $-10.768^{* * *}$ & $-4.178^{* * *}$ & $-16.386^{* * *}$ \\
\hline $\ln \mathrm{WA}$ & -0.694 & $-11.828^{* * *}$ & -0.925 & $-11.352^{* * *}$ \\
\hline $\ln \mathrm{WP}$ & $-3.631 * * *$ & $-13.420^{* * *}$ & $-8.175^{* * *}$ & $-16.199^{* * *}$ \\
\hline
\end{tabular}

8 Note: *,**, and *** show the significance level at $10 \%, 5 \%$, and $1 \%$ respectively.

9 Table 6. Pedroni Cointegration Test for Rice Crop

\begin{tabular}{|c|c|c|c|c|c|}
\hline & & $\begin{array}{c}\text { Unweighted } \\
\text { Statistic } \\
\end{array}$ & Prob. & $\begin{array}{l}\text { Weighted } \\
\text { Statistic }\end{array}$ & Prob. \\
\hline \multirow{4}{*}{ Within Panel } & Panel v-Statistic & -1.243 & 0.893 & -2.052 & 0.980 \\
\hline & Panel rho-Statistic & $-2.030 * *$ & 0.021 & $-2.037 * *$ & 0.021 \\
\hline & Panel PP-Statistic & $-6.952 * * *$ & 0.000 & $-6.608 * * *$ & 0.000 \\
\hline & Panel ADF-Statistic & $-3.272 * * *$ & 0.001 & $-2.591 * * *$ & 0.005 \\
\hline \multirow{3}{*}{ Between Panel } & Group rho-Statistic & -0.969 & 0.166 & & \\
\hline & Group PP-Statistic & $-7.273 * * *$ & 0.000 & & \\
\hline & Group ADF-Statistic & $-2.912 * * *$ & 0.002 & & \\
\hline
\end{tabular}

Note: ${ }^{*}, * *$, and ${ }^{* * *}$ show the significance level at $10 \%, 5 \%$, and $1 \%$ respectively.

11 Table 7. Pedroni Cointegration Test for Wheat Crop

\begin{tabular}{|l|l|l|l|l|l|}
\hline & & $\begin{array}{l}\text { Un-Weighted } \\
\text { Statistic }\end{array}$ & Prob. & $\begin{array}{l}\text { Weighted } \\
\text { Statistic }\end{array}$ & Prob. \\
\hline \multirow{5}{*}{ Within Panel } & Panel v-Statistic & 0.900 & 0.184 & 0.278 & 0.391 \\
\cline { 2 - 6 } & Panel rho-Statistic & $-3.033^{* * *}$ & 0.001 & $-2.581^{* * *}$ & 0.005 \\
\cline { 2 - 6 } & Panel PP-Statistic & $-9.039^{* * *}$ & 0.000 & $-8.473^{* * *}$ & 0.000 \\
\cline { 2 - 6 } & Panel ADF-Statistic & $-2.280^{* *}$ & 0.011 & $-2.173^{* *}$ & 0.015 \\
\hline Between Panel & Group rho-Statistic & -1.199 & 0.115 & & \\
\cline { 2 - 6 } & Group PP-Statistic & $-8.146^{* * *}$ & 0.000 & & \\
\cline { 2 - 6 } & Group ADF-Statistic & $-1.581^{*}$ & 0.057 & & \\
\hline
\end{tabular}


Table 8. Regression Results (Rice Yield is the dependent variable)

\begin{tabular}{|l|l|l|l|c|}
\hline \multirow{3}{*}{ Variables } & \multicolumn{3}{|c|}{ Rice } \\
\cline { 2 - 5 } & \multicolumn{2}{|c|}{ FMOLS Model } & \multicolumn{2}{c|}{ DOLS Model } \\
\cline { 2 - 5 } & Coefficient & Prob. & Coefficient & Prob. \\
\hline $\ln$ RMiT & $2.319 * * *$ & 0.000 & $3.474 * * *$ & 0.000 \\
\hline & $(0.074)$ & & $(0.824)$ & 0.000 \\
\hline $\ln$ RMxT & $-2.606 * * *$ & 0.000 & $-3.879 * * *$ & 0.772 \\
\hline & $(0.060)$ & & $(0.887)$ & 0.004 \\
\hline $\ln R P$ & $-0.125 *$ & 0.093 & -0.034 & \\
\hline & $(0.075)$ & & $(0.116)$ & \\
\hline $\ln R A$ & $0.128 * * *$ & 0.000 & $0.103 * * *$ & $(0.036)$ \\
\hline & $(0.019)$ & & 0.79 & \\
\hline$R^{2}$ & 0.80 & & 0.77 & \\
\hline Adjusted R & 0.76 & & & \\
\hline
\end{tabular}

14 Note: ***, and $* * *$ show the significance level at $10 \%, 5 \%$, and $1 \%$ respectively. Standard error is in 15 parentheses.

16 Table 9. Regression Results (Wheat yield is the dependent variable)

\begin{tabular}{|c|c|c|c|c|}
\hline \multirow{2}{*}{ Variables } & \multicolumn{2}{|c|}{ FMOLS Model } & \multicolumn{2}{|c|}{ DOLS Model } \\
\hline & Coefficient & Prob. & Coefficient & Prob. \\
\hline \multirow[t]{2}{*}{$\operatorname{lnWMiT}$} & $2.520 * * *$ & 0.000 & $2.745^{* * *}$ & 0.000 \\
\hline & $(0.273)$ & & $(0.487)$ & \\
\hline \multirow[t]{2}{*}{$\operatorname{lnWMxT}$} & $-2.120 * * *$ & 0.000 & $-2.909 * *$ & 0.015 \\
\hline & $(0.532)$ & & $(1.193)$ & \\
\hline \multirow[t]{2}{*}{$\operatorname{lnWP}$} & $-0.053 * *$ & 0.015 & $-0.102 *$ & 0.075 \\
\hline & $(0.022)$ & & $(0.057)$ & \\
\hline \multirow[t]{2}{*}{$\operatorname{lnWA}$} & $-0.164 * * *$ & 0.000 & $-0.157 * * *$ & 0.007 \\
\hline & $(0.043)$ & & $(0.057)$ & \\
\hline $\mathrm{R}^{2}$ & 0.87 & & 0.86 & \\
\hline Adjusted $\mathrm{R}^{2}$ & 0.84 & & 0.83 & \\
\hline
\end{tabular}

17 Note: ***, and *** show the significance level at $10 \%, 5 \%$, and $1 \%$ respectively. Standard error is in 18 parentheses.

19 Table 10. Pooled Mean Group (PMG) Model (Rice yield is the dependent variable)

\begin{tabular}{|c|c|c|c|}
\hline Variables & Coefficient & Std. Error & Prob. \\
\hline & \multicolumn{2}{|c|}{ Long Run Equation } & \\
\hline $\ln \mathrm{RMiT}$ & 0.120 & 0.696 & 0.864 \\
\hline $\operatorname{lnRMxT}$ & $-3.840 * * *$ & 0.780 & 0.000 \\
\hline $\operatorname{lnRP}$ & $-0.251 * * *$ & 0.092 & 0.007 \\
\hline \multirow[t]{2}{*}{$\operatorname{lnRA}$} & $0.121 * * *$ & 0.035 & 0.001 \\
\hline & \multicolumn{2}{|c|}{ Short Run Equation } & \\
\hline ECT & $-0.419 * * *$ & 0.039 & 0.000 \\
\hline$\Delta \operatorname{lnRMiT}$ & $0.641 * *$ & 0.304 & 0.036 \\
\hline$\Delta \operatorname{lnRMxT}$ & $0.434 * * *$ & 0.154 & 0.005 \\
\hline$\Delta \operatorname{lnRP}$ & $0.070 * * *$ & 0.015 & 0.000 \\
\hline$\Delta \operatorname{lnRA}$ & -0.154 & 0.153 & 0.315 \\
\hline Constant & $9.368 * * *$ & 0.867 & 0.000 \\
\hline
\end{tabular}


22 Table 11. Pooled Mean Group (PMG) Model (Wheat yield is the dependent variable)

\begin{tabular}{|c|c|c|c|}
\hline Variables & Coefficient & Std. Error & Prob. \\
\hline & \multicolumn{3}{|c|}{ Long Run Equation } \\
\hline $\operatorname{lnWMiT}$ & $0.821 *$ & 0.426 & 0.055 \\
\hline $\ln W M x T$ & $-1.700 *$ & 0.941 & 0.072 \\
\hline $\operatorname{lnWP}$ & $-0.106 * *$ & 0.046 & 0.022 \\
\hline \multirow[t]{2}{*}{$\ln W A$} & $-0.170 * * *$ & 0.048 & 0.000 \\
\hline & \multicolumn{3}{|c|}{ Short Run Equation } \\
\hline ECT & $-0.308 * * *$ & 0.056 & 0.000 \\
\hline$\Delta \ln W M i T$ & -0.094 & 0.099 & 0.341 \\
\hline$\Delta \ln W M x T$ & -0.147 & 0.206 & 0.477 \\
\hline$\Delta \ln W P$ & $0.029 * * *$ & 0.006 & 0.000 \\
\hline$\Delta \ln \mathrm{WA}$ & -0.135 & 0.159 & 0.394 \\
\hline Constant & $4.032 * * *$ & 0.731 & 0.000 \\
\hline
\end{tabular}

23 Note: $* * *$, and $* * *$ show the significance level at $10 \%, 5 \%$, and $1 \%$ respectively.

Table 12. Dumitrescu-Hurlin Panel Causality Tests (Rice yield is the dependent variable)

\begin{tabular}{|c|c|c|c|}
\hline Hypothesis & W-Stat. & Zbar-Stat. & Prob. \\
\hline $\operatorname{lnRMiT} \nRightarrow \ln R Y$ & 0.884 & -0.396 & 0.692 \\
\hline $\ln R Y \nRightarrow \ln R M i T$ & 0.596 & -1.027 & 0.304 \\
\hline $\ln R M x T \nRightarrow \ln R Y$ & 0.887 & -0.388 & 0.698 \\
\hline $\ln R Y \nRightarrow \ln R M x T$ & $5.206 * * *$ & 9.072 & 0.000 \\
\hline $\ln R P \nRightarrow \ln R Y$ & 1.111 & 0.101 & 0.919 \\
\hline $\ln R Y \nRightarrow \ln R P$ & $4.556^{* * *}$ & 7.648 & 0.000 \\
\hline $\ln R A \nRightarrow \ln R Y$ & $2.082 * *$ & 2.229 & 0.026 \\
\hline $\ln R Y \nRightarrow \ln R A$ & 2.025 & 2.105 & 0.035 \\
\hline $\ln R M x T \nRightarrow \ln R M i T$ & $0.288^{*}$ & -1.700 & 0.089 \\
\hline $\ln R M i T \nRightarrow \ln R M x T$ & $4.691 * * *$ & 7.943 & 0.000 \\
\hline $\operatorname{lnRP} \nRightarrow \ln R M i T$ & $2.981 * * *$ & 4.197 & 0.000 \\
\hline $\operatorname{lnRMiT} \nRightarrow \operatorname{lnRP}$ & $6.154 * * *$ & 11.148 & 0.000 \\
\hline $\ln R A \nRightarrow \ln R M i T$ & 1.190 & 0.274 & 0.784 \\
\hline $\ln \mathrm{RMiT} \nRightarrow \ln \mathrm{RA}$ & 0.764 & -0.658 & 0.511 \\
\hline $\ln R P \nRightarrow \ln R M x T$ & 1.453 & 0.850 & 0.395 \\
\hline
\end{tabular}




\begin{tabular}{|l|l|l|l|}
\hline $\operatorname{lnRMxT} \nRightarrow \operatorname{lnRP}$ & 1.038 & -0.059 & 0.953 \\
\hline $\operatorname{lnRA} \nRightarrow \operatorname{lnRMxT}$ & & & \\
\hline $\operatorname{lnRMxT} \nRightarrow \operatorname{lnRA}$ & $2.655^{* * *}$ & 3.484 & 0.001 \\
\hline & 0.805 & -0.569 & 0.569 \\
\hline $\operatorname{lnRA} \nRightarrow \operatorname{lnRP}$ & & & \\
\hline $\operatorname{lnRP} \nRightarrow \operatorname{lnRA}$ & $5.275^{* * *}$ & 9.223 & 0.000 \\
\hline
\end{tabular}

Note: $*, * *$, and $* * *$ show the significance level at $10 \%, 5 \%$, and $1 \%$ respectively.

Table 13. Pairwise Dumitrescu-Hurlin Panel Causality Tests (Wheat yield is dependent variable)

\begin{tabular}{|c|c|c|c|}
\hline Null Hypothesis & W-Stat. & Zbar-Stat. & Prob. \\
\hline $\ln \mathrm{WMiT} \nRightarrow \ln \mathrm{WY}$ & 1.397 & 0.727 & 0.467 \\
\hline $\operatorname{lnWY} \nRightarrow \ln W M i T$ & $5.762 * * *$ & 10.290 & 0.000 \\
\hline $\ln W M x T \nRightarrow \ln W Y$ & $3.102 * * *$ & 4.464 & 0.000 \\
\hline $\ln W Y \nRightarrow \ln W M x T$ & 1.690 & 1.371 & 0.171 \\
\hline $\ln W P \nRightarrow \ln W Y$ & $4.384 * * *$ & 7.272 & 0.000 \\
\hline $\ln W Y \nRightarrow \ln W P$ & 0.737 & -0.717 & 0.473 \\
\hline $\ln \mathrm{WA} \nRightarrow \ln \mathrm{WY}$ & $2.148 * *$ & 2.372 & 0.018 \\
\hline $\ln \mathrm{WY} \nRightarrow \ln \mathrm{WA}$ & 1.577 & 1.122 & 0.262 \\
\hline $\ln W M x T \nRightarrow \ln W M i T$ & $2.643 * * *$ & 3.457 & 0.001 \\
\hline $\operatorname{lnWMiT} \nRightarrow \ln W M x T$ & 1.650 & 1.282 & 0.200 \\
\hline $\operatorname{lnWP} \nRightarrow \ln W M i T$ & $2.576^{* * * *}$ & 3.311 & 0.001 \\
\hline $\operatorname{lnWMiT~} \nRightarrow \ln W P$ & 0.494 & -1.250 & 0.211 \\
\hline $\ln \mathrm{WA} \nRightarrow \ln \mathrm{WMiT}$ & 1.410 & 0.758 & 0.449 \\
\hline $\ln \mathrm{WMiT} \nRightarrow \ln \mathrm{WA}$ & 1.577 & 1.123 & 0.261 \\
\hline $\operatorname{lnWP} \nRightarrow \ln W M x T$ & $3.540 * * *$ & 5.423 & 0.000 \\
\hline $\ln \mathrm{WMxT} \nRightarrow \ln \mathrm{WP}$ & 1.233 & 0.369 & 0.712 \\
\hline $\ln W A \nRightarrow \ln W M x T$ & 0.632 & -0.947 & 0.344 \\
\hline $\ln W M x T \nRightarrow \ln W A$ & 1.228 & 0.358 & 0.720 \\
\hline $\ln W A \nRightarrow \ln W P$ & 0.428 & -1.394 & 0.163 \\
\hline $\ln W P \nRightarrow \ln W A$ & 0.550 & -1.126 & 0.260 \\
\hline
\end{tabular}



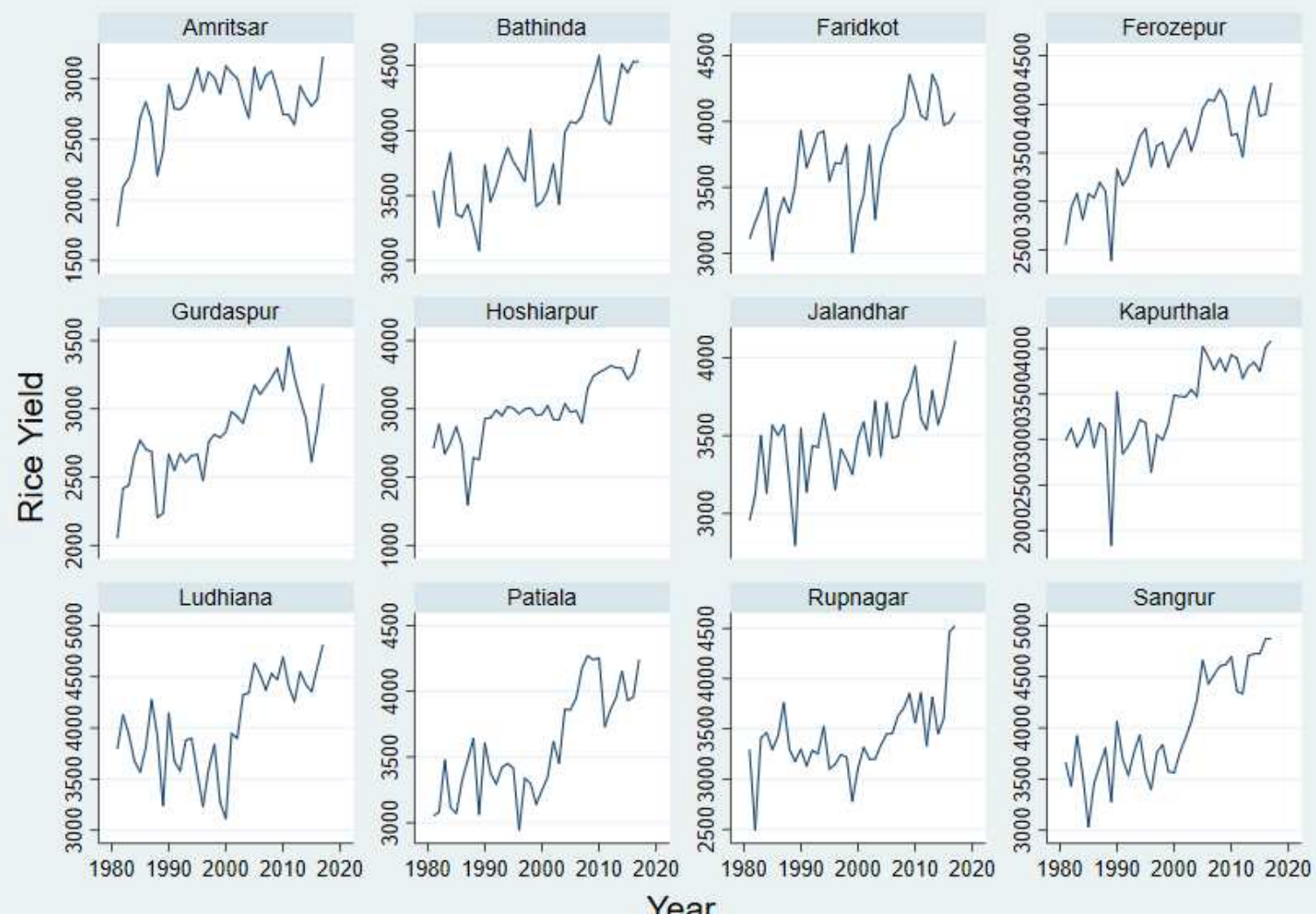

Figure 1. Trends in Rice Yield in Punjab during 1981-2017 

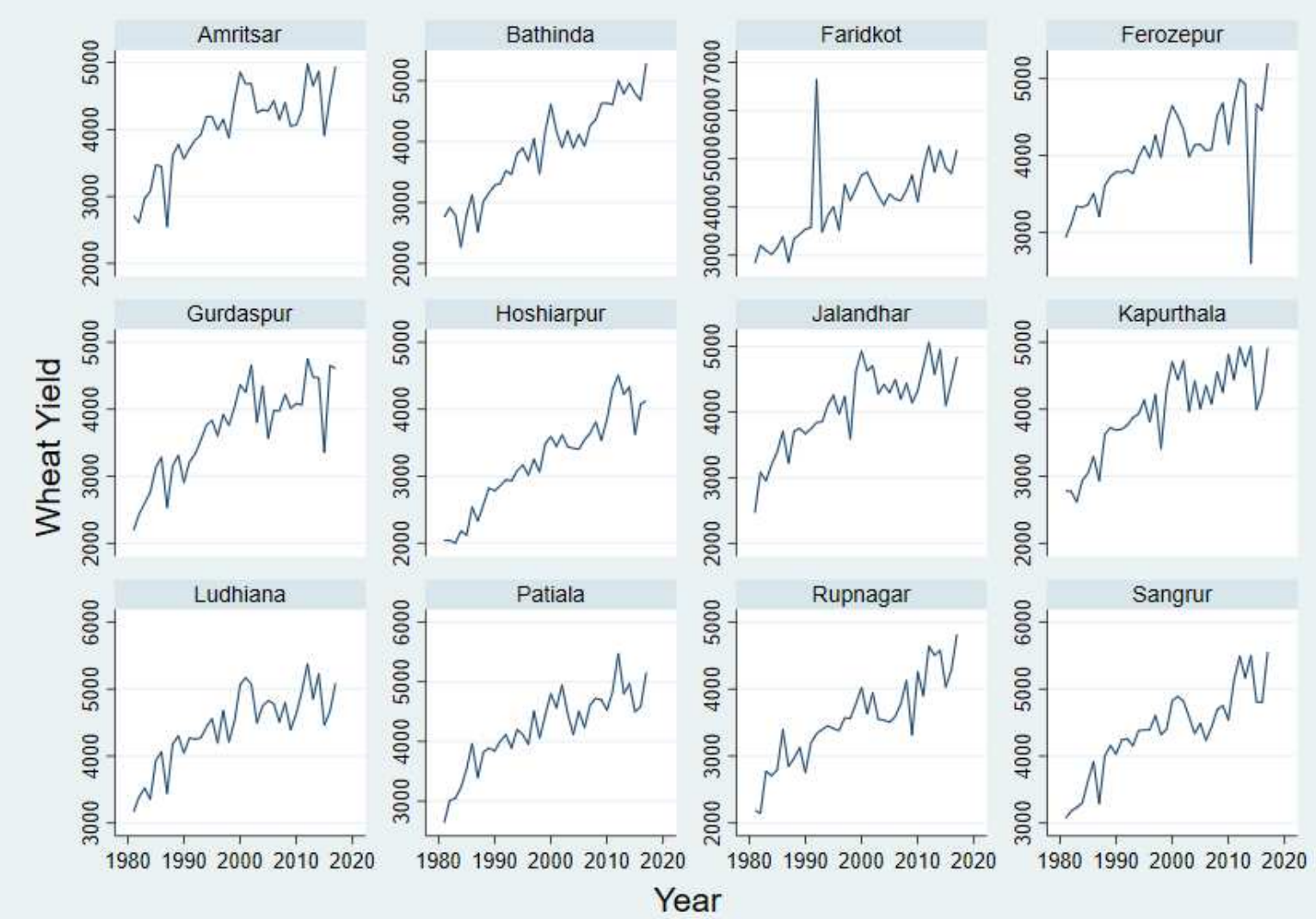

35

\section{Year}

Figure 2. Trends in Wheat Yield in Punjab during 1981-2017 

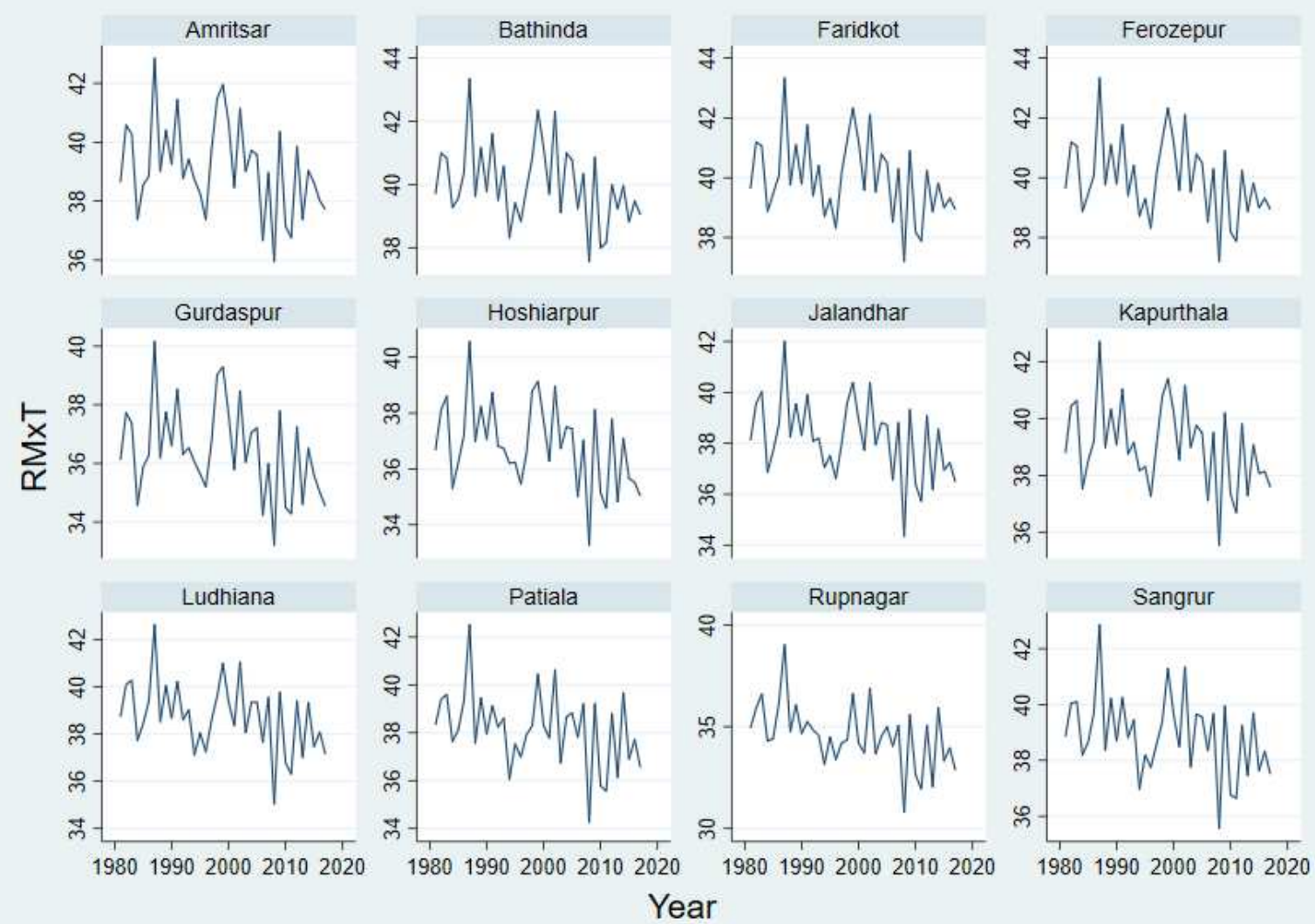

Figure 3. Trends in Rice Average Maximum Temperature in Punjab during 1981-2017 

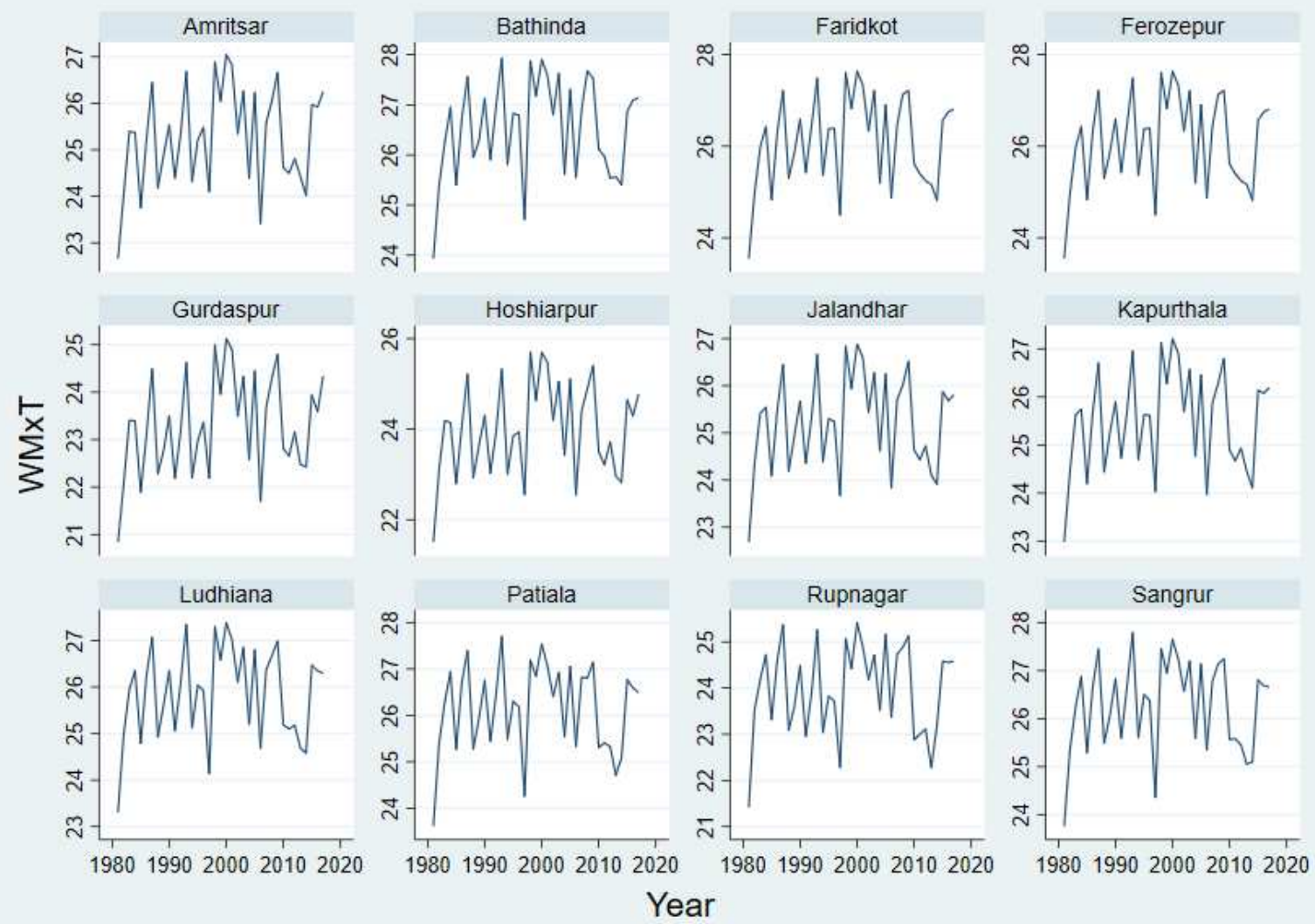

Figure 4. Trends in Wheat Average Maximum Temperature in Punjab during 1981-2017 

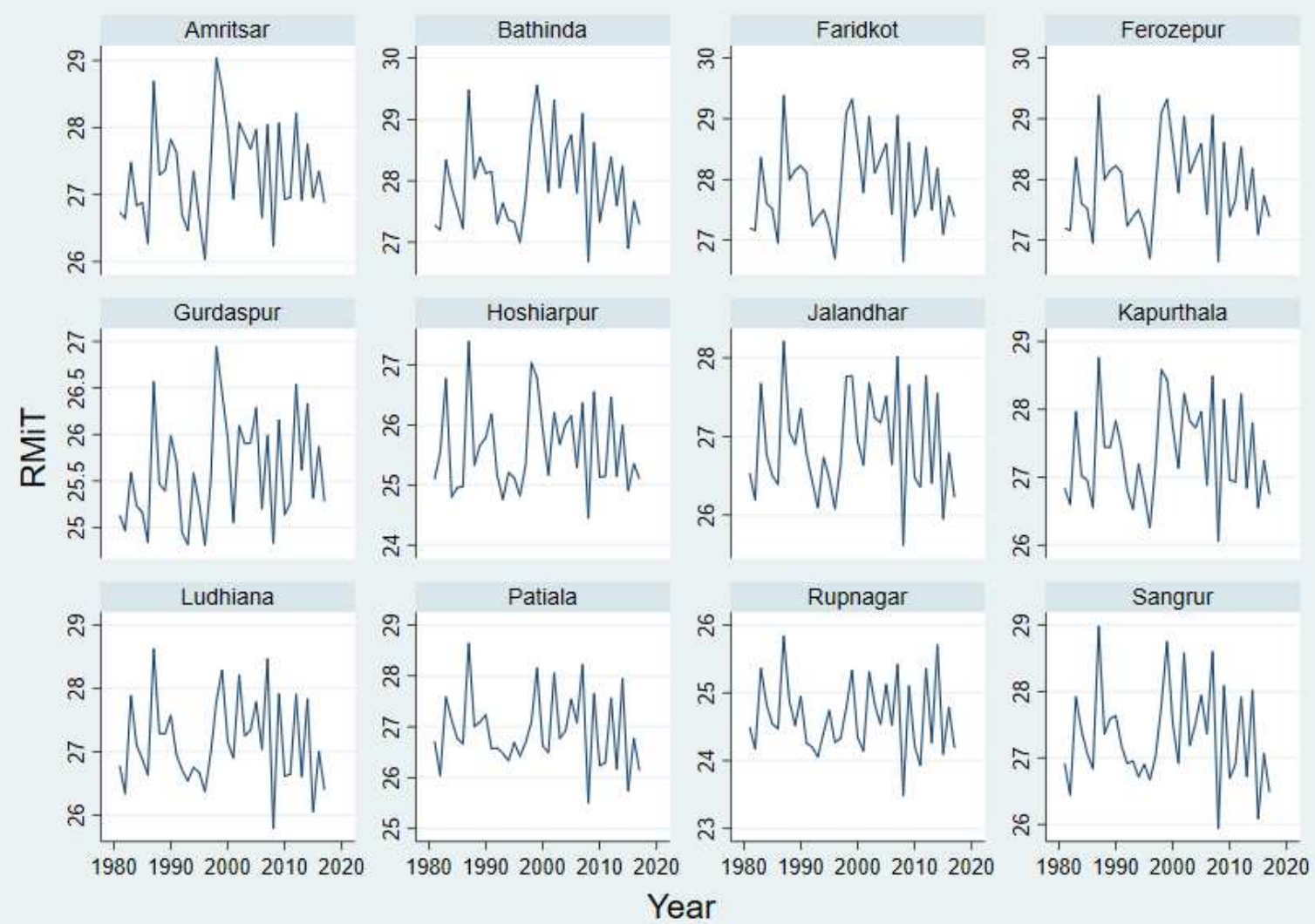

Figure 5. Trends in Rice Average Minimum Temperature in Punjab during 1981-2017 

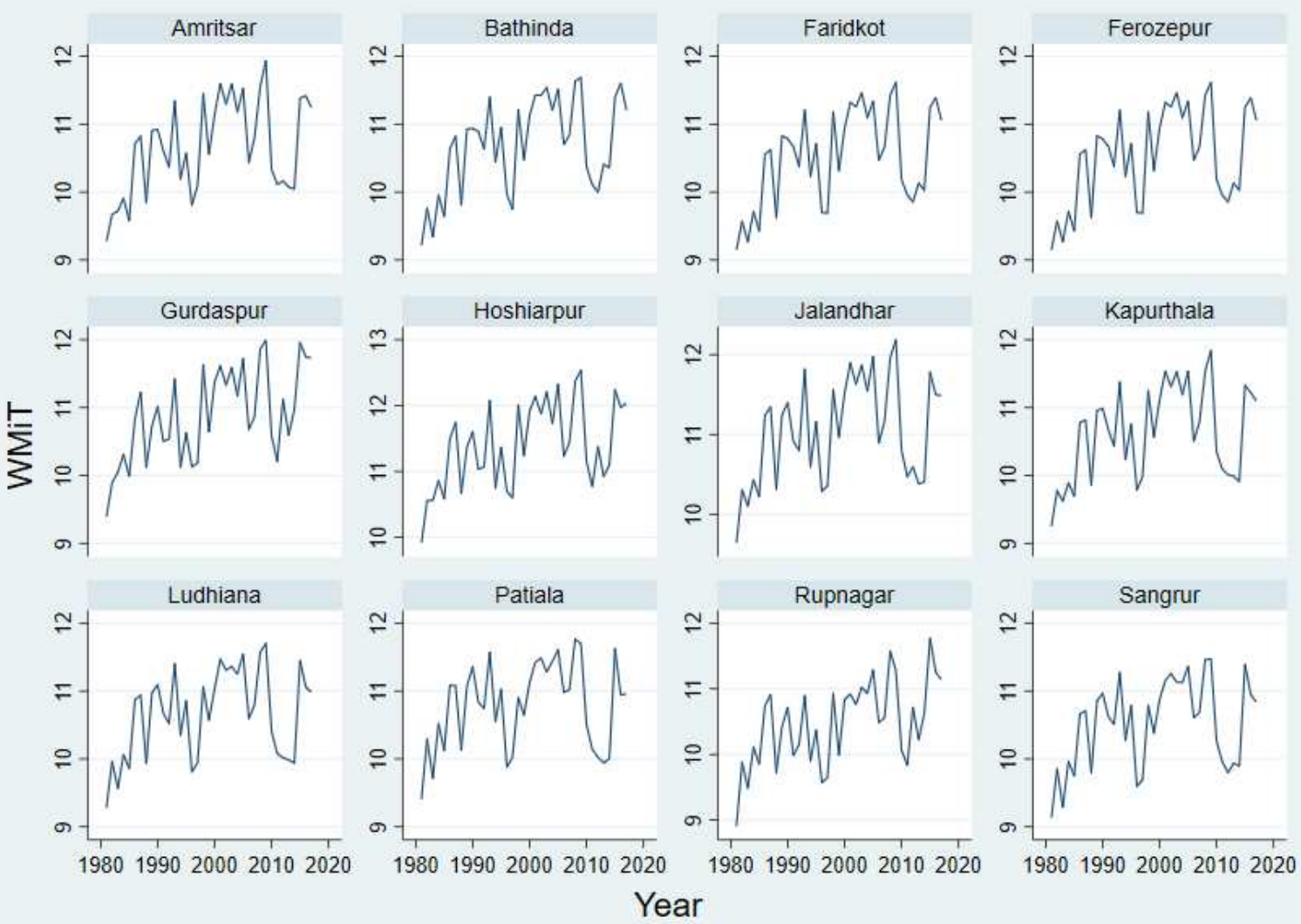

Figure 6. Trends in Wheat Average Minimum Temperature in Punjab during 1981-2017 

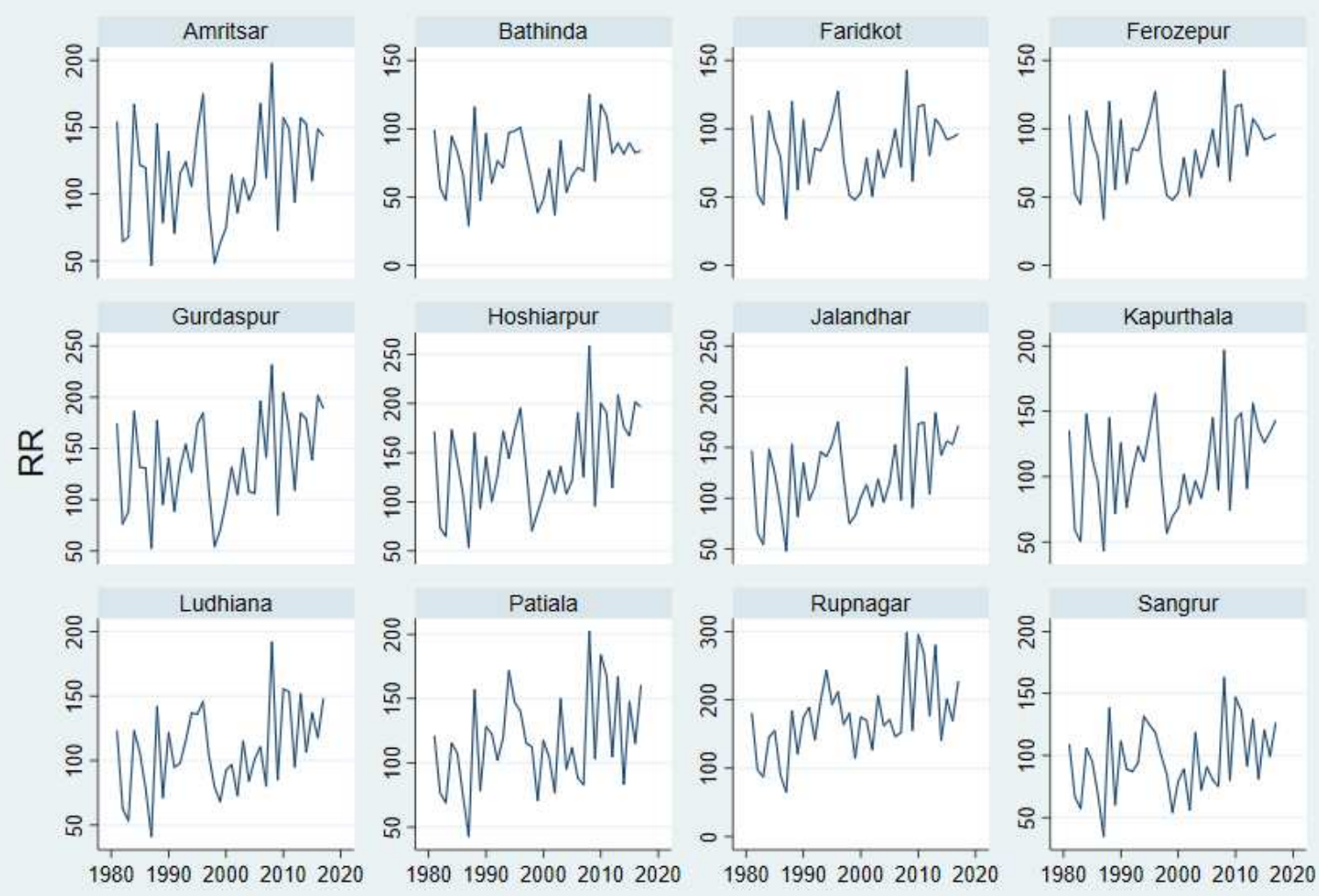

Year

Figure 7. Trends in Average Annual Rainfall during Rice Season in Punjab during 1981-2017 


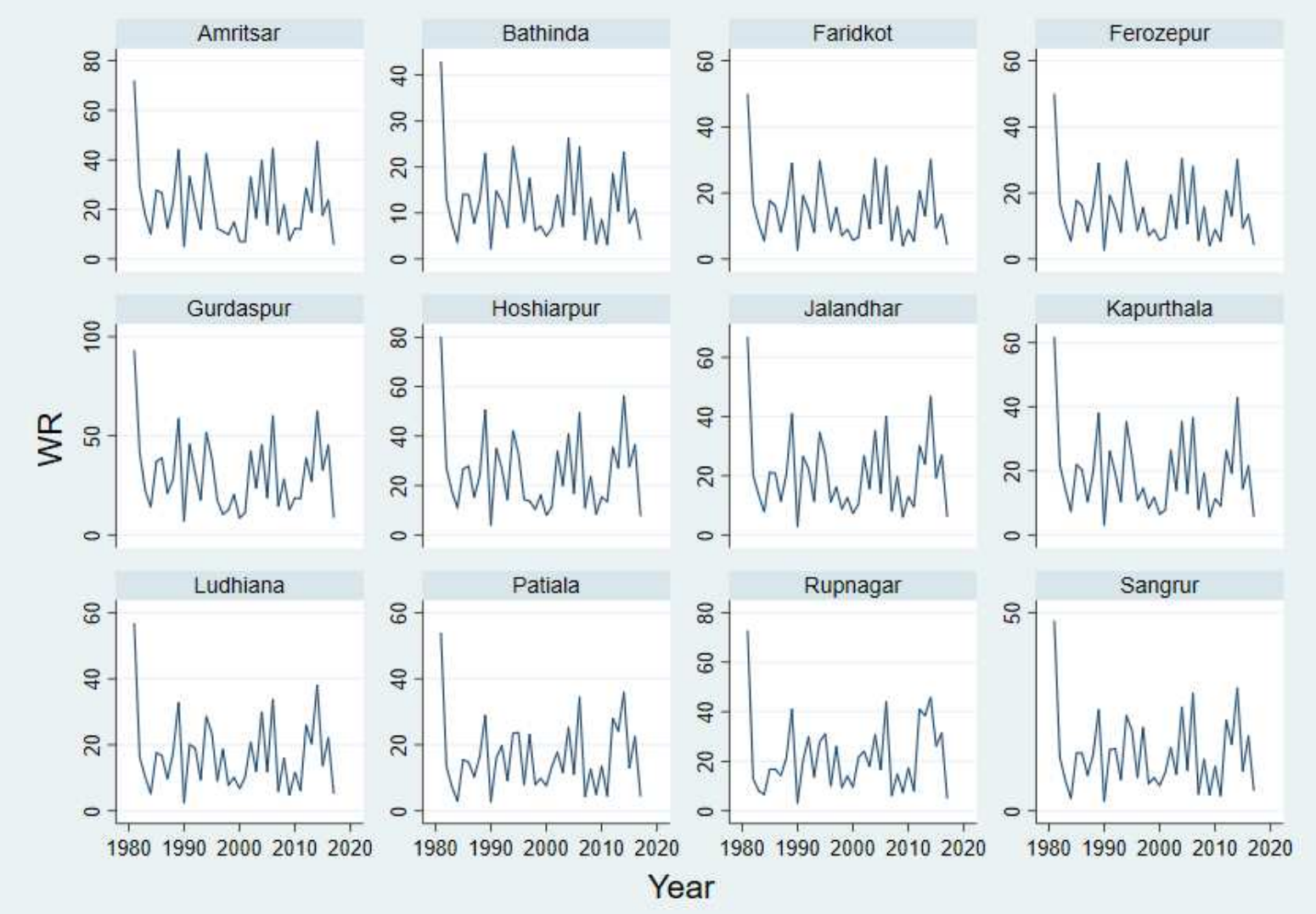

48

Figure 8. Trends in Average Annual Rainfall during Wheat Season in Punjab during 1981-2017

50

51

52

53 